\title{
Organic carbon and microbial activity in marine sediments on a global scale throughout the Quaternary
}

\author{
In revision at Geochimica et Cosmochimica Acta
}

Douglas E. LaRowe*, ${ }^{*}$, Sandra Arndt ${ }^{2}$, James A. Bradley ${ }^{1}$, Ewa Burwicz ${ }^{3}$, Andrew W. Dale ${ }^{3}$ and Jan P. Amend ${ }^{1,4}$

${ }^{1}$ Department of Earth Sciences, University of Southern California, Los Angeles, CA, USA ${ }^{2}$ Department of Geosciences, Environment and Society, Free University of Brussels, Brussels, Belgium

${ }^{3}$ GEOMAR Helmholtz Centre for Ocean Research Kiel, Germany

${ }^{4}$ Department of Biological Sciences, University of Southern California, Los Angeles, CA, USA

*To whom correspondences should be addressed: larowe@usc.edu

Keywords: reaction transport model, deep biosphere, microbial ecology, organic carbon degradation, Quaternary, bioenergetics, reactive continuum model, deep carbon, Holocene, Pleistocene 
Microbial degradation of organic carbon in marine sediments is a key driver of global element cycles on multiple time scales. However, it is not known to what depth microorganisms alter organic carbon in marine sediments or how microbial rates of organic carbon processing change with depth, and thus time since burial, on a global scale. To better understand the connection between the dynamic carbon cycle and life's limits in the deep subsurface, we have combined a number of global data sets with a reaction transport model (RTM) describing first, organic carbon degradation in marine sediments deposited throughout the Quaternary Period and second, a bioenergetic model for microbial activity. The RTM is applied globally, recognizing three distinct depositional environments - continental shelf, margin and abyssal zones. The results include the masses of particulate organic carbon, POC, stored in three sediment-depth layers: bioturbated Holocene $\left(1.7 \times 10^{17} \mathrm{~g} \mathrm{C}\right)$, non-bioturbated Holocene $\left(2.6 \times 10^{18} \mathrm{~g} \mathrm{C}\right)$ and Pleistocene $\left(1.4 \times 10^{20} \mathrm{~g} \mathrm{C}\right)$ sediments. The global depth-integrated rates of POC degradation have been determined to be $6.8 \times 10^{13}, 1.2 \times 10^{14}$ and $1.2 \times 10^{14} \mathrm{~g} \mathrm{C} \mathrm{yr}^{-1}$ for the same three layers, respectively. A number of maps depicting the distribution of $\mathrm{POC}$, as well as the fraction that has been degraded have also been generated. Using POC degradation as a proxy for microbial catabolic activity, total heterotrophic processing of POC throughout the Quaternary is estimated to be between $10^{-11}-10^{-6} \mathrm{~g} \mathrm{C} \mathrm{cm}^{-3} \mathrm{yr}^{-1}$, depending on the time since deposition and location. Bioenergetic modeling reveals that laboratory-determined microbial maintenance powers are poor predictors of sediment biomass concentration, but that cell concentrations in marine sediments can be accurately predicted by combining bioenergetic models with the rates of POC degradation determined in this study. Our model can be used to quantitatively describe both the carbon cycle and microbial activity on a global scale for marine sediments less than 2.59 million years old.

\section{Introduction}

Marine sediments consist of unconsolidated rock particles, organisms, volcanic debris, authigenic precipitates, cosmogenic deposits, water and organic carbon. They constitute the uppermost layer of most oceanic crust and also blanket nearly $31 \%$ of the continental crust that lies under seawater (Cogley, 1984). By covering $3.6 \times 10^{8} \mathrm{~km}^{2}$ (Eakins and Sharman, 2010), they comprise one of the largest features of Earth's surface and therefore one of its largest habitats and carbon reservoirs. The transformation of organic carbon in sediments not only sustains a massive biosphere, but in the most dynamic upper tens of centimeters of sediments, the microbial oxidation of organic carbon alters the saturation state of pore waters with respect to calcium carbonate minerals. This consequently affects carbonate burial, an important part of the Walker thermostat that keeps Earth's temperature within livable limits (Emerson and Bender, 1981; Walker et al., 1981). Furthermore, microbial oxidation of organic carbon in sediments drives Fe, Mn and S cycles, processes that influence ocean chemistry (e.g., Berner, 1980; Middelburg, 1989; Boudreau and Ruddick, 1991; Canfield, 1993; Tromp et al., 1995; Jørgensen and Kasten, 2006; Thullner et al., 2009). In addition, the (selective) microbial degradation of organic carbon throughout the sediment column can impact the various sets of isotopic, biogenic/authigenic mineral and biomarker data that are used to interpret paleoenvironmental records (Zonneveld et al., 2010; Wehrmann et al., 2013; Freitas et al., 2017). On geologic time scales, the microbial processing of organic carbon in marine sediments plays a major role in controlling levels of oxygen and $\mathrm{CO}_{2}$ in the atmosphere (Rothman, 2002; Berner, 2006) and the amount of $\mathrm{CH}_{4}$ that is stored in near-shore sediments (Burwicz et al., 2011; Wadham et al., 2013). 
The fate of organic carbon in sediments, and therefore the degree to which it impacts global biogeochemical cycles, is a function of the rate at which it is deposited and the type of environment in which it is delivered. Although approximately half of POC delivered to sediments is oxidized by oxygen-consuming microorganisms (Jørgensen and Kasten, 2006), other organisms using $\mathrm{NO}_{3}{ }^{-}$ , $\mathrm{SO}_{4}{ }^{2-}$ and $\mathrm{Fe}-$ and $\mathrm{Mn}$ - oxides as electron acceptors flourish, driving, $\mathrm{S}, \mathrm{N}, \mathrm{Fe}$ and $\mathrm{Mn}$ cycles. POC can also be fermented, reduced to $\mathrm{CH}_{4}$, or, with increasing depth and temperature, converted abiotically into hydrocarbons. Despite the critical role that marine sediment POC has driving global biogeochemical cycles, estimates for the modern-day flux of POC to the seafloor vary considerably. A review of the literature reveals a factor of 40 between the lowest and highest global POC flux estimates, spanning 137 to 5,739 $\mathrm{Tg} \mathrm{C} \mathrm{yr}^{-1}$ (Burdige, 2007; Wallmann et al., 2012). Similarly, although the delivery of POC to the ocean floor is known to vary geographically and temporally (e.g., Arndt et al., 2006; Arndt et al., 2009; Wehrmann et al., 2013), these factors are poorly constrained.

Rates of microbial organic carbon degradation in marine sediments can vary by at least eight orders of magnitude across ocean basins (Middelburg, 1989), and modeling studies suggest that POC deposited tens of millions of years ago is still being slowly metabolized by microbial communities (Arndt et al., 2006; Røy et al., 2012; D'Hondt et al., 2015; LaRowe and Amend, 2015b; Bradley et al., 2018c, b). Since most sediment microorganisms depend on POC as an energy source, improved knowledge of the distribution and rates of POC degradation on a global scale is crucial to determining the extent, size and activity level of the vast deep biosphere. Furthermore, the ability of microorganisms to process ancient POC calls into question some of the limits of life - i.e., how slowly can microorganisms metabolize, and over what time-scales can they remain viable.

The purpose of this communication is to simultaneously estimate the global distribution of marine sediment organic carbon, and the activity levels of microorganisms consuming it, throughout the Quaternary Period $(0-2.59 \mathrm{Ma})$. By doing so, we will improve understanding of the connection between short and long term carbon cycles, and the spatial distribution of microbial biomass in a large portion of the deep biosphere. The modeling approach that we take builds on recent efforts to quantitatively describe marine sediments as a habitat for microbial life on a global scale (LaRowe et al., 2017). Several present-day global data sets, including bathymetry, sedimentation rates, POC concentrations at the sediment-water interface (SWI) and POC reactivity feed into these modeling efforts to provide maps of the distribution of organic carbon in global marine sediments. In addition, these data are used to constrain how much organic carbon resides and has been degraded in marine sediments deposited since the beginning of the Quaternary, which include the most microbially active portions of marine sediments. The resulting rates of organic carbon degradation and a bioenergetic power model are then combined to estimate the amount of power available to microorganisms in typical shelf, margin and abyssal sediments. Taken together, this global-scale quantitative description of carbon dynamics in marine sediments has implications for the long-term diagenesis of sediments and the limits of life.

\section{Methods}

A 1-D reaction transport model, RTM, at a spatial resolution of $1 / 4^{0} \times 14^{0}$ was used to calculate the amount of POC deposited, stored and degraded in marine sediments throughout the Quaternary. Due to dramatic differences in Earth's climate system between the Holocene, ( 0 to 11,700 yrs ago) and Pleistocene (11,700 to 2.59 Myrs ago) Epochs, many of the parameterizations and therefore results shown below are given for these time periods. The Holocene sediment layers 
is further partitioned into bioturbated and non-bioturbated sections (see Fig.1). The bioenergetic modeling carried out in this study uses the calculated rates of POC degradation to assess the activity levels and numbers of microorganisms in marine sediments.

Although most of the values of the parameters required to run the RTM are specified per grid cell, some of the model parameters are not well-constrained on a global basis (see Table 1). Consequently, we have selected values of these parameters that are characteristic of sediments found in three oceanic domains: shelf, margin and abyss (see Fig. 2). The location of each domain is defined by water depth (Vion and Menot, 2009): shelf environments roughly correspond to water depths $<200 \mathrm{~m}$, with the exception of the Antarctic region where shelf area corresponds to water depths $<500 \mathrm{~m}$; areas deeper than $\sim 3500 \mathrm{~m}$ are taken to be abyssal plain; sediments under other water depths are referred to as margins. It follows that continental shelf underlies about $6.33 \%$ of ocean surface area, margins make up $10.78 \%$ and the abyssal domain constitutes the remaining $82.89 \%$.

\subsection{Reaction transport model}

The one-dimensional conservation equation for POC in porous media is given by (e.g., Berner, 1980; Boudreau, 1997):

where $P O C$ corresponds to the concentration of particulate organic carbon ( $\mathrm{g} \mathrm{C} \mathrm{cm}^{-3}$ dry sediment); $t$ stands for time; $D_{b}\left(\mathrm{~cm}^{2} \mathrm{yr}^{-1}\right)$ refers to the bioturbation coefficient; $\omega\left(\mathrm{cm} \mathrm{yr}^{-1}\right)$ represents the sedimentation rate and $R_{P O C}$ denotes the rate of heterotrophic organic carbon degradation in units of $\mathrm{g} \mathrm{C} \mathrm{cm}^{-3}$ dry sediment $\mathrm{yr}^{-1}$. The porosity, $\phi$, of marine sediments in the shelf, margin and abyss domains was calculated as a function of depth, $z(\mathrm{~m})$ using a standard formulation commonly used in basin-to-global scale porosity studies (Athy, 1930) that assumes steady state compaction:

$$
\phi(z)=\phi_{0} \exp \left(-c_{0} z\right)
$$

where $\phi_{0}$ denotes the porosity at the SWI and $c_{0}\left(\mathrm{~m}^{-1}\right)$ stands for the compaction length scale, which characterizes how a given sediment type will compact under its own weight.

Quaternary sediments were divided into three layers: bioturbated Holocene (top $10 \mathrm{~cm}$ (Boudreau, 1997)), non-bioturbated Holocene (10 cm to sediments $<11,700 \mathrm{yrs}$ ) and Pleistocene $(11,700 \leq 2.59 \mathrm{Myrs})$. In the locations shown in Fig. 3, the bottom-most sediments on the seafloor are younger than the beginning of the Pleistocene. As a result, calculations covering these areas do not reach back 2.59 Myrs, but to the amount of time indicated in Fig. 3. Sediment mixing was assumed to be constant over the bioturbated layer and non-existent immediately below it.

The rate of POC degradation, $R_{P O C}$, was described using a reactive continuum model, RCM. The RCM assumes a continuous, yet dynamic distribution of organic compounds comprising a range of reactivities and reproducing the often-observed decrease in apparent POC reactivity with depth, and thus burial age (Boudreau and Ruddick, 1991). Within the RCM, $R_{P O C}$ is given by:

$$
R_{P O C}=-\int_{0}^{\infty} k \cdot o m(k, t) d k
$$


where $\operatorname{om}(k, t)$ denotes a probability density function that determines the concentration of organic carbon having a degradability between $k$ and $k+d k$ at time $t$, with $k$ being analogous to a reaction rate constant. The initial distribution of organic compounds, $\operatorname{om}(k, 0)$, may take different mathematical forms, but cannot be inferred by observations. Here, a gamma function was used, as proposed by Boudreau and Ruddick (1991), following Aris (1968) and Ho and Aris (1987). Assuming first order degradation kinetics, the initial $(t=0)$ distribution of om over $k$ is given by:

$$
o m(k, 0)=\frac{P O C_{0} \cdot i a^{v} \cdot k^{v-1} \cdot e^{-i a \cdot k}}{\Gamma(v)}
$$

where $P O C_{0}$ is the initial organic carbon content (at the SWI), $\Gamma$ is the gamma function, $i a$ (yr) is the average lifetime of the more reactive components of the mixture and $v$ is a dimensionless parameter determining the shape of the distribution near $k=0$. The adjustable, positive parameters $i a$ and $v$ completely determine the shape of the initial distribution of organic carbon compounds over the range of $k$ values and thus the overall reactivity of POC. High $v$ and low ia values indicate a mixture of organics dominated by compounds that are typically degraded rapidly. Low $v$ and high $i a$ values indicate a larger fraction of less reactive compounds that degrade slowly. See Arndt et al. (2013) for a more in-depth description of these parameters.

Although the choice of the gamma function is partly guided by mathematical expedience, it also has the advantage of describing the temporal evolution of organic carbon profiles observed in sediments. Assuming steady state conditions $\left(\frac{\partial P O C}{\partial t}=0\right)$ and a known organic carbon content at the sediment water interface, $P O C_{0}$, the change in the bulk particulate organic carbon concentration as a function of depth, $P O C(z)$, is given by Boudreau and Ruddick (1991):

$$
\operatorname{POC}(z)=P O C_{0} \cdot\left(\frac{i a}{i a+a g e(z)}\right)^{v}
$$

where $\operatorname{age}(z)$ refers to the age of the sediment layer at depth $z$. While the RCM has proven successful in predicting the down-core evolution of organic carbon reactivity in deep sediments, its application to the bioturbated layer of the sediment is compromised by the difficulty of constraining the age of organic carbon in bioturbated sediments. Meile and Van Cappellen (2005) showed that, within the bioturbated zone, the age distribution of reactive species is not only controlled by bioturbation and sedimentation but also by the reactivity of the species in question. Similar to the approach proposed by Dale et al. (2015) and Dale et al. (2016), we use a multi-G approximation of the RCM for bioturbated sediment. This means that within the bioturbated zone, POC is represented by 500 distinct fractions that are degraded according to a first-order organic carbon degradation rate law with a degradation rate constant, $k_{i}$ :

$$
R_{P O C}=\sum_{i=1}^{500} k_{i} \cdot P O C_{i}(z)
$$

where

$$
P O C_{i}(0)=F_{i} \cdot P O C
$$

The initial proportion of total organic carbon in fraction $i, F_{i}$, as well as its respective reactivity, $k_{i}$, can be determined through the initial probability density function that determines the 
concentration of organic carbon having a degradability between $k$ and $k+d k$ at time 0 (Eq. 3). The initial fraction of total POC characterized by a distinct reactivity $k$ is given by:

$$
f(k, 0)=\frac{o m(k, 0)}{P O C_{0}}=\frac{i a^{v} \cdot k^{v-1} \cdot e^{-i a \cdot k}}{\Gamma(v)}
$$

The initial fraction of $\mathrm{POC}$ within the reactivity range between 0 and $k$, i.e., having a reactivity $\leq$ $k$, is then given by integrating Eq. (8), assuming $i a, v, k>0$ :

$$
F(k, 0)=\int_{0}^{k} f(0, k) d k=\int_{0}^{k} \frac{i a^{v} \cdot k^{v-1} \cdot e^{-i a \cdot k}}{\Gamma(v)} d k=
$$

$$
\frac{i a^{v} \cdot k^{v} \cdot(i a \cdot k)^{-v}(\Gamma(v)-\Gamma(v, i a \cdot k))}{\Gamma(v)}=\left(\frac{1-\Gamma(v, i a \cdot k)}{\Gamma(v)}\right)
$$

where $\Gamma(v, i a \cdot k)$ denotes the inverse gamma function.

In the bioturbated sediment layer, the RCM was approximated by dividing the reactivity range $k=\left[10^{-15}, 10^{(-\log (i a)+2)}\right]$ into 500 equal reactivity bins, $k_{j}$, thus ensuring a comprehensive approximation of the gamma function defined by the respective $i a$ and $v$ values. The initial fraction, $F_{i}$, of total POC within the reactivity bin $k_{j-1}$ and $k_{j}$ (and thus with reactivity $k_{i}=k_{j-1}+\left(k_{j}-k_{j-1}\right) / 2$ ) in the $500 \mathrm{G}$ model can then be calculated as:

$$
F_{i}=F\left(k_{j}, 0\right)-F\left(k_{j-1}, 0\right)
$$

The most reactive fraction, $F_{500}$, with reactivity $k_{500}=10^{-\log (i a)+2} \mathrm{yr}^{-1}$ was calculated on the basis of the upper incomplete gamma function:

$$
F_{500}=\int_{k_{500}}^{\infty} f\left(k_{500}, 0\right) d k=\frac{\Gamma\left(v, i a \cdot k_{500}\right)}{\Gamma(v)}
$$

The derived rate constants were then used in Eq. (1) by expressing $R_{P O C}$ according to Eq. (5) to determine POC concentrations and degradation rates in the bioturbated Holocene layer $(<10 \mathrm{~cm})$. For this purpose, Eq. (1) was solved analytically. Assuming steady state conditions, the general solution of Eq. (1) for each organic carbon fraction $i$ is given by:

$$
P O C_{i}(z)=A_{i} e^{\left(a_{i} z\right)}+B_{i} e^{\left(b_{i} z\right)}
$$

where

$$
a_{i}=\frac{\omega-\sqrt{\omega^{2}+4 D_{b} \cdot k_{i}}}{2 D_{b}}
$$

$$
b_{i}=\frac{\omega+\sqrt{\omega^{2}+4 D_{b} \cdot k_{i}}}{2 D_{b}}
$$

and 
The integration constants $A_{i}$ and $B_{i}$ are defined by the chosen boundary conditions. Here, we apply a known concentration at the sediment-water interface $\left(P O C(0)=P O C_{0}\right)$ and assume continuity (equal flux and concentration) across the bottom of the bioturbated layer $\left(P O C(z b i o)=P O C_{z b i o}\right.$; $\left.\left.\frac{-D_{b} d P O C}{d z}\right|_{z b i o}=0\right)$.

Below the bioturbated Holocene zone, the values of $\operatorname{age}(z)$ that are required to evaluate Eq. (5) were calculated using burial rates, $\omega(z)$, porosity depth profiles, $\phi(z)$, and the apparent age of organic carbon at the lower limit of the bioturbated Holocene zone, agezbio. The latter was calculated by inserting $P O C_{b i o}$ and $a g e_{z b i o}$ into Eq. (5) for $P O C(z)$ and age(z), respectively, and solving for the age:

$$
\operatorname{POC}(z)=\sum_{i=1}^{500} P O C_{i}(z)
$$

Assuming an exponentially decreasing porosity, Eq. (2), and steady-state compaction, the burial velocity, $\omega$, at depth $z$ is then (e.g., Berner, 1980):

$$
a g e_{z b i o}=\frac{-i a \cdot\left(\exp \left(\ln \left(P O C_{b i o} / P O C_{0}\right) / v\right)-1\right)}{\exp \left(\ln \left(P O C_{b i o} / P O C_{0}\right) / v\right)}
$$
velocity, $a$, at dept $z$ is then (e.g., Berner, 1980$)$ :

$$
\omega(z)=\left(\frac{1-\phi_{0}}{1-\phi(z)}\right) \omega_{0}
$$

where $\omega_{0}$ corresponds to the burial velocity at the SWI. The age of a given sediment layer at depth $z$ below the bioturbated Holocene zone, age (z), is given by e.g., Berner (1980):

$$
\operatorname{age}(z)=\int_{0}^{z} \omega^{-1} d z
$$

Substituting Eq. (17) into Eq. (18) results in

303 The age of POC below the bioturbated Holocene zone is thus given by: 


$$
\operatorname{age}(z)=a g e_{z b i o}+\frac{z+\frac{\phi_{0}}{c_{0}} \cdot\left(\exp \left(-c_{0} \cdot\left(z-z_{b i o}\right)\right)-1\right)}{\omega_{0} \cdot\left(1-\phi_{0}\right)}
$$

305

The depth distribution of organic carbon in marine sediments deposited since the beginning of the Quaternary can thus be calculated with knowledge of the sedimentation rate, level of bioturbation, porosity structure, bulk organic carbon concentration at the SWI and the distribution of organic compounds across the reactivity range at the SWI.

\subsection{Total POC budget and burial efficiency}

The fraction of total POC preserved in a layer of sediment that accumulated over a given time interval, $\overline{P E_{i}}$, is given as the ratio of the total amount of POC stored in the $i$ th sediment layer $\left(i=\right.$ bioturbated Holocene $\left(0-z_{b i o}\right)$, non-bioturbated Holocene $\left(z_{b i o}-z_{\text {holo }}\right)$, Pleistocene $\left(z_{\text {holo }}-\right.$ $\left.\left.z_{\text {pleis }}\right)\right), \overline{P O C_{i}}\left(\mathrm{~g} \mathrm{C} \mathrm{cm}^{-2}\right)$ and the total steady state input of POC to that respective layer, $\overline{I_{i}},\left(\mathrm{~g} \mathrm{C} \mathrm{cm}^{-}\right.$ $\left.{ }^{2}\right)$ :

$$
\overline{P E_{i}}=\overline{P O C_{i}} / \overline{I_{i}}
$$

where

$$
\overline{P O C_{i}}=\int_{z_{i}}^{z_{i-1}} \operatorname{POC}(z) d z
$$

and

$$
\overline{I_{i}}=\operatorname{POC}\left(z_{i-1}\right) \cdot \Delta z_{i}
$$

POC $\left(z_{i-1}\right)$ refers to the concentration of POC at the upper boundary of a sediment horizon of interest. For instance, the explicit version of the right hand side of Eq. (24) used to calculate the amount of POC delivered to the non-bioturbated Holocene layer of sediments would be $\operatorname{POC}\left(z_{\text {bio }}\right) \cdot \Delta z_{\text {holo }}$.

The amount of POC degraded in the $i$ th layer, $\overline{R_{i}}$, is given by

$$
\overline{R_{i}}=\int_{z_{i}}^{Z_{i-1}} k(z) \cdot \operatorname{POC}(z) d z
$$

Carbon burial efficiencies, $B E(\%)$, which reveal the proportion of POC that has survived microbial degradation to a given sediment horizon, have also been calculated. Values of $B E$ are therefore a concise way of combining all the forces in an ecosystem that work to degrade and protect organic carbon. The way that burial efficiencies are calculated here reveals how much of the steady state flux of POC that has been deposited at the sediment water interface for each time period is buried through a particular depth horizon (i.e., zbio, zholo, zpleis). This is in contrast to how $B E$ is typically calculated, as a flux of POC through a particular sediment depth, which ignores differing sedimentation rates and thus the differing amounts of time that POC has been degraded. 
where

Here, $B E$ is taken to be the amount of POC that has fluxed through a given sediment depth, $F_{z}\left(\mathrm{~g} \mathrm{C} \mathrm{cm}^{-2} \mathrm{yr}^{-1}\right)$, relative to the steady state depositional flux through the sediment water interface of the respective depth layers/time periods, $F_{\text {dep }}\left(\mathrm{g} \mathrm{C} \mathrm{cm}^{-2} \mathrm{yr}^{-1}\right)$ :

$$
B E=F_{z} / F_{d e p}
$$

$$
F_{z}=\left.(1-\phi(z)) D_{b} \frac{d P O C(z)}{d z}\right|_{z}+(1-\phi(z)) \omega \cdot \operatorname{POC}(z)
$$

Note that for sediment depth $z \geq z b i o$, transport becomes purely advective and the dispersion term in Eq. (27) is dropped. Values of $F_{\text {dep }}$ were calculated using

$$
F_{\text {dep }}=\left.(1-\phi(0)) D_{b} \frac{d P O C(0)}{d z}\right|_{0}+(1-\phi(0)) \omega \cdot \operatorname{POC}(0)
$$

Note that $\left.\frac{d P O C(0)}{d z}\right|_{0}$ is determined by the first derivative of Eq. (12) and thus varies with POC reactivity, bioturbation coefficient and sedimentation rate. Also note that two different sets of values for $\omega$, the sedimentation rate, are used: one for Holocene sediments and the other for Pleistocene sediments (see below).

\subsection{Parameters and forcings}

As described below, each grid cell has particular values of $P O C_{0}, \omega, D_{b}, i a$ (for the baseline scenario) and $z$, whereas values of $\phi_{0}, v, i a$ (for the low and high-reactivity scenarios) and $c_{0}$ are assigned to grid cells depending on whether their water depth places them in the shelf, margin or abyss domains (see Fig. 2 and Table 1).

The concentration of $\mathrm{POC}$ at the sediment water interface, $P O C_{0}$, for Holocene sediments was taken from a global compilation of these values (Seiter et al., 2004; Romankevich et al., 2009) (see Wallmann et al. (2012)). Holocene sedimentation rates, $\omega$, were calculated using an algorithm that correlates water depth and sedimentation rate according to a double logistic equation (Burwicz et al., 2011), building on Holocene sedimentation data from over 500 stations (Betts and Holland, 1991; Colman and Holland, 2000; Seiter et al., 2004). The total global sedimentation rate for the Pleistocene was taken to be the same as that for the Holocene, but the distribution of these rates was changed to take into account lower sea level (Menard and Smith, 1966; Peltier, 1994; Rohling et al., 1998; Ludwig et al., 1999), altered patterns of dust deposition and the transport of ice-rafted material (Lisitzin, 1996) during the Pleistocene. Consequently, sedimentation rates on margins were increased by a factor of five over a $500 \mathrm{~km}$ wide zone around continental margins (Burwicz et al., 2011), while sedimentation velocities on shelves were decreased such that global sedimentation during the Pleistocene matched that of the Holocene. The resulting Pleistocene sedimentation rates were used with the distribution of Holocene POC to calculate the distribution of Pleistocene POC concentrations at the SWI (see Wallmann et al. (2012).

The bioturbation coefficient, $D_{b}$, was calculated as a function of water depth based on a compilation of empirical data collected by Middelburg et al. (1997). Its values range from 27 to $0.59 \mathrm{~cm}^{2} \mathrm{yr}^{-1}$, decreasing in magnitude as water depth increases. It is constant throughout the bioturbated Holocene zone and immediately drops to zero beneath it. 
For simplicity and clarity, values of porosity at the sediment water interface, $\phi_{0}$, and the compaction length scale, $c_{0}$, were chosen to describe the shelf, margin and abyss based on sediments that are representative of these domains (Hantschel and Kauerauf, 2009) (see Table 1).

The reactivity of organic carbon deposited onto the seafloor and its evolution during burial is notoriously difficult to constrain. In general, the organic carbon reactivity parameters of the $1 \mathrm{G}-$ model, $k$, and the RCM, $i a$ and $v$, are determined by finding a best fit to observed POC and porewater profiles at specific sites (e.g., Arndt et al., 2013). However, because heterotrophic degradation of organic carbon involves a plethora of different organisms that breakdown a wide range of organic compounds under varying environmental conditions, using a number of different terminal electron acceptors and producing a large range of different product compounds, attempts to identify statistically significant relationships between organic carbon degradation rate constants and individual factors such as water depth, deposition rate, or organic carbon flux on a global scale have not been definitively established. Stolpovsky and colleagues have proposed empirical relationships among benthic $\mathrm{O}_{2}$ and $\mathrm{NO}_{3}{ }^{-}$fluxes to estimate parameter values for POC degradation models that employ power-law and multi-G functions (Stolpovsky et al., 2015, 2018), but there is currently no general framework that can be used to estimate the ia and $v$ parameters in the RCM on a global scale. Consequently, organic carbon reactivities are associated with large uncertainties.

Here, we considered three levels of organic carbon reactivity for each domain: a baseline scenario as well as minimum and maximum reactivity parameter sets based on the lower and upper bounds of published values, henceforth referred to as the low- and high-reactivity scenarios (See Table 1). The baseline scenario is constrained based not only on a global parameter compilation, but also on observations that the $v$ parameter values do not vary much between sites, while the $i a$ parameter can vary over orders of magnitude (e.g. Boudreau and Ruddick, 1991; Arndt et al., 2013). Therefore, for the baseline scenario we chose a constant $v$ parameter of 0.125 , characteristic of fresh organic carbon (Boudreau et al., 2008). Values of the $i a$ parameter are correlated with sedimentation rates based on a global compilation of RCM applications (Arndt et al., 2013). This approach accounts for order-of-magnitude changes in ia due to factors that control OM transit times from its source to deposition. The baseline scenario thus reflects typically observed RCM parameter variability across various depositional environments, while the parameters chosen for the high and low reactivity scenarios span nearly the entire range of observed values reported in the literature (e.g., Boudreau and Ruddick, 1991; Arndt et al., 2013).

\subsection{Bioenergetics calculations}

We have taken the approach used by LaRowe and Amend (2015a; 2015b) to relate the rates and energetics of organic carbon degradation to the number of microbial cells that an environment

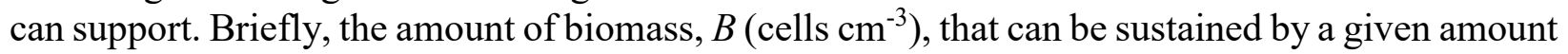
of energy per unit time, (or power) is calculated with

$$
B=\frac{P_{s}}{P_{d}}
$$

where $P_{s}$ and $P_{d}\left(\mathrm{~W}\right.$ or $\left.\mathrm{J} \mathrm{s}^{-1}\right)$ denote the cellular power supply and demand, respectively. Values of $P_{s}$ are calculated using

$$
P_{s}=\Delta G_{r} \cdot R_{P O C}
$$


where values of $R_{P O C}$ are calculated using Eqn. (3) and $\Delta G_{r}$ is computed as described below. The values of $P_{d}$ used for organisms oxidizing POC with oxygen and sulfate are the median values of those collected by LaRowe and Amend (2015a): for aerobic heterotrophy it is 2,375 $\mathrm{fW}_{\text {cell }}^{-1}$ and for sulfate reduction it is $77 \mathrm{fW}$ cell $^{-1}$.

The amount of energy available from the oxidation of organic carbon by aerobic and

$$
\begin{aligned}
& \mathrm{CH}_{3} \mathrm{COO}^{-}+2 \mathrm{O}_{2} \rightarrow \mathrm{H}^{+}+2 \mathrm{HCO}_{3}^{-} \\
& \mathrm{CH}_{3} \mathrm{COO}^{-}+\mathrm{SO}_{4}^{2-} \rightarrow \mathrm{HS}^{-}+2 \mathrm{HCO}_{3}^{-}
\end{aligned}
$$

and the Gibbs energy function,

$$
\Delta G_{r}=\Delta G_{r}^{0}+R T \ln Q_{r}
$$

where $\Delta G_{r}^{0}$ and $Q_{r}$ refer to the standard molal Gibbs energy and the reaction quotient of the indicated reaction, respectively, $R$ represents the gas constant, and $T$ denotes temperature in Kelvin. Values of $\Delta G_{r}^{0}$ were calculated using the revised-HKF equations of state (Helgeson et al., 1981; Tanger and Helgeson, 1988; Shock et al., 1992), the SUPCRT92 software package (Johnson et al., 1992), and thermodynamic data taken from (Shock and Helgeson, 1988; Shock et al., 1989; Shock and Helgeson, 1990; Sverjensky et al., 1997; Schulte et al., 2001). Values of $Q_{r}$ are calculated using

$$
Q_{r}=\prod_{i} a_{i}^{v_{i}}
$$

where $a_{i}$ stands for the activity of the $i$ th species and $v_{i}$ corresponds to the stoichiometric coefficient of the $i$ th species in the reaction of interest (e.g., Rxns. (31) and (32)). Molalities of the $i$ th species, $m_{i}$, were converted into activities using individual activity coefficients of the $i$ th species $\left(\gamma_{i}\right)$,

$$
a_{i}=m_{i} \gamma_{i}
$$

Values of $\gamma_{i}$ were in turn computed as a function of temperature and ionic strength using an extended version of the Debye-Hückel equation (Helgeson, 1969).

Temperatures and pressures in marine sediments vary (LaRowe et al., 2017), as do concentrations of the reactants and products in Reactions (31) and (32). Hence, it is impossible to calculate single, globally relevant values of the Gibbs energies of organic carbon oxidation by $\mathrm{O}_{2}$ and $\mathrm{SO}_{4}{ }^{2-}$. However, to facilitate the bioenergetic analysis presented below, we have selected two sets of conditions for calculations of $\Delta G_{r}$. For shelf and margin sediments, we used $\Delta G_{r}=-81.5$ $\mathrm{kJ}$ (mol acetate) ${ }^{-1}\left(\mathrm{Rxn}(31), \log a_{i}\right.$ for acetate, $\mathrm{SO}_{4}{ }^{2-}, \mathrm{HS}^{-}$and $\mathrm{HCO}_{3}{ }^{-}$were taken to be -3.2, -2.6, 7.2 and -2.9 at $5^{\circ} \mathrm{C}$ and 100 bars of pressure), while for abyss sediments, $\Delta G_{r}=-841.6 \mathrm{~kJ}$ (mol acetate $)^{-1}\left(\mathrm{Rxn}(32), \log a_{i}\right.$ for acetate, $\mathrm{O}_{2}$ and $\mathrm{HCO}_{3}{ }^{-}$taken to be $-3.2,-3.5$ and $-2.9, \mathrm{pH}=8$ at $5^{\circ} \mathrm{C}$ and 400 bars of pressure). These assumptions effectively assume that POC is degraded by sulfate 
reducing organisms in shelf and margin settings and by aerobic metabolism in abyssal sediments (see Jørgensen and Kasten (2006) and D'Hondt et al. (2015)). Although other oxidants are used by microorganisms for degrading organic carbon in marine sediments, such as nitrate and $\mathrm{Fe}$-oxides, as well breakdown by fermenters, only $\mathrm{O}_{2}$ - and $\mathrm{SO}_{4}{ }^{2-}$-mediated $\mathrm{POC}$ degradation are considered here because the vast majority of marine sedimentary organic carbon is thought to be degraded via these pathways (Canfield et al., 2005; Jørgensen and Kasten, 2006; Thullner et al., 2009). Acetate is used as a proxy for organic carbon in Reactions (31) and (32) since there are thousands of organic compounds that microorganisms could be oxidizing and the identities (and likely, the thermodynamic properties) of the organic molecules consumed by microorganisms in natural settings is rarely known. In addition, the Gibbs energies of OM degradation are, on a per electron basis, much more sensitive to the identity of the electron acceptor than that of the organic compound (LaRowe and Van Cappellen 2011; LaRowe and Amend 2015a), so by focusing on the oxidant, we are capturing the first-order energetic differences of OM degradation in different environmental settings. Finally, it is worth noting that as a common fermentation byproduct, acetate is a regular constituent of marine sediment pore water (Glombitza et al., 2015 and references therein).

\section{Results}

The reaction transport model described above has been used to assess the fate of POC in shelf, margin and abyss sediments according to three POC reactivity scenarios for sediments deposited throughout the Quaternary. The results are presented for the bioturbated Holocene (top $10 \mathrm{~cm}$ ), non-bioturbated Holocene (from $10 \mathrm{~cm}$ to sediments that are 11,700 yrs old) and Pleistocene (from 11,700 to 2.59 Myrs old for locations where sediments reach this age; see Fig. 3) sediment layers (see Fig. 2). The rates of POC degradation in typical shelf, margin and abyss domains are also used to illustrate the power levels sustaining microbial communities in these environments as a function of depth.

\subsection{Structure of sediment layers}

Due to spatially heterogeneous sedimentation rates (Wallmann et al., 2012), the thickness of Holocene and Pleistocene sedimentary layers varies considerably as a function of longitude and latitude. In Fig. 4a, it can be seen that Holocene sediments can extend to about $15 \mathrm{~m}$ below the SWI (yellow colors) in many coastal locations, particularly in high northern latitudes, the eastern side of South America, between Southeast Asia and Indonesia, the East China Sea and the Arafura Sea. Most of the rest of the ocean's Holocene sediments are $<1 \mathrm{~m}$ thick (dark blue colors in Fig. 4a). The thickness of Pleistocene sediments, shown in Fig. 4b, also displays the impact of differential sedimentation rates. Using a different scale, Pleistocene sediments are shown to be up to $1000 \mathrm{~m}$ thick, mostly in high latitudes. Looking like a teal halo, there is a considerable proportion of Pleistocene sediments between $\sim 500-700 \mathrm{~m}$ thick surrounding most land-masses. As is also illustrated in Fig. 3, the areas close to land where there are little to no Pleistocene sediments, colored dark blue, were largely not covered by seawater during this Epoch (Hay, 1994).

The volumes of the bioturbated Holocene, non-bioturbated Holocene and Pleistocene sediment layers, as well as their relative distributions in the shelf, margin and abyss domains are shown in Fig. 4c. These values are given in units of $\mathrm{cm}^{3}$ because microbial biomass concentrations are often reported in units of cell $\mathrm{cm}^{-3}$. The $10 \mathrm{~cm}$-thick bioturbated Holocene layer has a total volume of $3.6 \times 10^{19} \mathrm{~cm}^{3}$, containing $1.1-1.7 \times 10^{17} \mathrm{~g}$ of organic carbon (Table 2); the vast majority of this layer is located in the abyss domain. The non-bioturbated Holocene layer, by 
comparison, is an order of magnitude more voluminous, at $\sim 4.1 \times 10^{20} \mathrm{~cm}^{3}$, with $7.2-26 \times 10^{17}$ $\mathrm{g}$ organic $\mathrm{C}$ (Table 2). Most of the Pleistocene sediments, contrary to the non-bioturbated Holocene layer, are in the abyss domain with a minuscule proportion on shelves (Fig. 4c). Interestingly, even though the Pleistocene lasted $\sim 220$ times longer than the Holocene, Pleistocene-aged sediments only occupy about 100 times the volume of non-bioturbated Holocene sediments. This is partly attributable to lower sedimentation rates and lower sea levels before the Holocene and the compaction of sediments that has taken place at depth.

\subsection{Burial Efficiency}

The percentage of POC that has been buried through the bioturbated Holocene, nonbioturbated Holocene, and Pleistocene sediments layers relative to the amount that fluxed through the SWI is shown in Fig. 5 and Table 2 for the three POC reactivity scenarios considered in this study. The spatial distribution of $B E \mathrm{~s}$ in all three reactivity scenarios is heterogeneous, though less so in the high reactivity case. Because all of the plots are presented on the same scale, the variability in $B E$ for the high-reactivity case is best seen in Table 2 . Figures $5 \mathrm{~g}, \mathrm{~h}, \mathrm{i}$ and Table 2 show that less than a tenth of a percent of POC fluxing through the SWI is buried beneath the bioturbated Holocene and non-bioturbated Holocene sediment layers for the high reactivity scenario and that $B E \mathrm{~s}$ in abyssal sediments are around $2 \%$. By contrast, values of $B E$ for abyssal sediments in the low reactivity scenario range from $50-64 \%$ for the bioturbated Holocene, nonbioturbated Holocene and Pleistocene scenarios, although the global $B E$ s are less than $7 \%$ in both the Holocene layers. $B E$ in the baseline scenario range from $20 \%$ through the bioturbated Holocene layer to about $12 \%$ through the non-bioturbated Holocene and 24\% through the Pleistocene layers.

\subsection{POC budget for each time interval}

The masses of POC stored in the bioturbated Holocene, non-bioturbated Holocene and Pleistocene sediment layers for the shelf, margin and abyss domains are given in Table 3 for all reactivity scenarios. The different scenarios show similar amounts of POC retained in the baseline and low-reactivity cases, but considerably lower amounts in the high-reactivity scenario. It can also be seen that more POC is calculated to remain in all three sediment layers in shelf settings and the margins in the Pleistocene layer for the baseline scenario than the low-reactivity scenario case. This is because the ia parameter in the POC reactivity model, which greatly influences the reactivity of POC on relatively short timescales, varies with water depth in the baseline reactivity scenario, and is fixed for the low reactivity case. So, for some water depths, POC is more reactive in the low-reactivity scenario than in the baselines case.

The integrated amounts of POC stored in each sediment layer for the baseline scenario are shown in the maps displayed in Fig. 6. The distribution patterns of POC in the top two layers is nearly uniform (Fig 6a), with some outliers in near-coastal regions for the non-bioturbated sediments (green colors in Fig. 6b). Not surprisingly, orders of magnitude more POC is stored in the much larger volume of Pleistocene sediments (Fig. 6c).

\subsection{Microbial rates of POC degradation}

The overall rates of POC degradation in the three sediments layers are shown in Table 4 for each of the three reactivity scenarios. Illustrating the importance of the $i a$ and $v$ RCM parameters on the most recently deposited sediments, the rates of POC degradation are orders of magnitude higher in the high reactivity scenario in bioturbated Holocene sediments than in the 
other two cases. However, global rates are lower in the deeper sediments for the high reactivity scenario than for the baseline and low reactivity scenarios, which are nearly the same.

The integrated rates of POC degradation by microorganisms in the different sediments are shown in Fig. 7 for the baseline scenario. For each layer, the rates vary by orders of magnitude depending on, mostly, distance from land. The rates tend to be highest in shelf and margin sediment layers, with abyssal rates up to several order of magnitude lower.

The rates of POC degradation at the bottoms of the non-bioturbated Holocene and Pleistocene sediment layers are shown in Fig. 8 for the baseline reactivity scenario. As in the amounts of POC stored and the integrated rates of POC degradation, there are strong geographical differences in rates at the oldest sediments for each layer. POC degradation rates at the bottom of Holocene typically fall between $10^{-9}$ and $10^{-7} \mathrm{~g} \mathrm{C} \mathrm{cm}^{-3} \mathrm{yr}^{-1}$ (Fig. 8a), while those at the bottom of the Pleistocene tend to be two orders of slower; the sediments near land in high northern latitudes are one exception, however (Fig. 8b).

\subsection{POC power}

The amount of power available to microorganisms due to the oxidation of POC in representative shelf, margin and abyss sediments is shown as a function of sediment depth in Fig 9a. For all three environments, the power available from POC degradation spans several orders of magnitude from the SWI to sediments that were deposited at the beginning of the Pleistocene. The somewhat complex shapes of these curves are due to the different algorithms used to calculate POC degradation in the bioturbated Holocene layer and the rest of the sediment column. Despite their apparent separation on this log-log plot, the power supply in margin and abyss sediments is nearly the same, starting at $10^{-11} \mathrm{~W} \mathrm{~cm}^{-3}$ and dropping to $\sim 4 \times 10^{-15} \mathrm{~W} \mathrm{~cm}^{-3}$. Values of $P_{s}$ in the shelf setting start two orders of magnitude higher than the other locations and decrease to about $10^{-14} \mathrm{~W} \mathrm{~cm}^{-3}$ at the bottom of the Pleistocene.

In order to produce global scale estimates of biomass density, one would need to know which reaction is being catalyzed for energy and its corresponding value of $\Delta G_{r}$. This requires data such as pore water composition that are not globally available. However, the representative power densities shown in Fig. 9a can be compared to published and collated maintenance powers, $P_{d}$, of microorganisms carrying out aerobic and sulfate-consuming heterotrophy (LaRowe and Amend, 2015a) to estimate how many microorganisms are simply carrying out maintenance functions in marine sediments (if growth is accounted for, additional model parameters would be needed, e.g., LaRowe and Amend (2016); Bradley et al., (2018a)). The amount of biomass that could be supported on maintenance power alone for the three representative sediment columns shown in Fig. 9a are shown in Fig. 9b. The number of cells at the SWI for representative shelf, margin and abyss sediments are $4 \times 10^{4}, 280$ and $5 \mathrm{cell} \mathrm{cm}^{-3}$, dropping to less than $1 \mathrm{cell} \mathrm{cm}^{-3}$ for sediments that were deposited at the beginning of the Pleistocene.

\section{DISCUSSION}

There are published estimates of the global flux of organic carbon to marine sediments, the amount degraded in surface sediments and the quantity buried (e.g., Burdige (2007)). However, there are no estimates quantifying the physical distribution of these fluxes, the amounts of organic carbon expected to be found at particular depths and locations, and therefore, the metabolic rates of microorganism in the deep biosphere on a global scale. The results presented in this study demonstrate not only where organic carbon is likely distributed in marine sediments in three dimensions, but how much has been degraded by microbial activity and how much remains in 
particular horizons over the last $\sim 2.6$ million years in three dimensions. This information is useful for understanding the long-term carbon cycle, the extent of the marine sedimentary biosphere and presented below.

\subsection{Quaternary organic carbon budget}

An understanding of organic carbon preservation and burial in marine sediments is critical to interpret the sedimentary isotope record and quantify carbon sources and sinks over geological time scales (Berner, 2004). Here, we reveal the most comprehensive quantitative assessment of the amount of POC stored and degraded in marine sediments deposited in three dimensions over the Quaternary Period. As such, it is difficult to compare most of the results of this study to other published studies since so few of these quantities have been reported. In addition, the lack of a common reference frame can complicate comparisons of, for example, carbon burial efficiency, $B E$, with the existing literature. For instance, when values of $B E$ are specified, they are nearly always based on the fraction of POC at a defined sediment depth relative to the amount arriving at the sediment water interface. This approach ignores differing sedimentation rates and thus the differing amounts of time that POC has undergone degradation. It is illustrative to note that the age of POC in sediments one meter beneath the SWI in the South Pacific Gyre can reach one million years, while for some coastal settings, POC at the same depth could be as young as a few thousand years.

Despite these obstacles, we can compare our results to some of the few attempts to quantify the global organic carbon budget in marine sediments. In a review, Burdige (2007) reports that the total rate of POC degradation in marine sediments is between 702 and $3,127 \times 10^{12} \mathrm{~g} \mathrm{C} \mathrm{yr}^{-1}$, though it is unclear over what depth or time interval these values refer. Our results show that in the baseline scenario, the integrated rates of $\mathrm{POC}$ degradation in the bioturbated Holocene, non-bioturbated Holocene and Pleistocene layers are $328 \times 10^{12}, 194 \times 10^{12}$ and $97.5 \times 10^{12} \mathrm{~g} \mathrm{C} \mathrm{yr}^{-1}$, respectively, totaling $620 \times 10^{12} \mathrm{~g} \mathrm{C} \mathrm{yr}^{-1}$ for all marine sediments $\leq 2.59 \mathrm{Myr}$.

Another quantity published in the literature that could be compared to our results is the mass of POC stored in sediments. Eglington and Repeta (2014), based on earlier reports (Hedges, 1992; Hedges and Oades, 1997), declared that "recent sediments" contain $1.50 \times 10^{17} \mathrm{~g}$ of organic C. Our calculations estimate that the bioturbated layer alone (top $10 \mathrm{~cm}$ ) contains a similar amount, $1.7 \times 10^{17} \mathrm{~g} \mathrm{C}$ (baseline scenario), but our non-bioturbated Holocene sediments contain more than an order of magnitude more, $2.6 \times 10^{18} \mathrm{~g} \mathrm{C}$. In this case, comparisons to the literature rely on the meaning of the word "recent." By our calculations, Quaternary sediments, which could be considered recent, contain $1.4 \times 10^{20} \mathrm{~g} \mathrm{C}$. This is about two orders of magnitude less that the estimated total amount of organic carbon in marine sediments, $1.25 \times 10^{22} \mathrm{~g} \mathrm{C}$ (Ronov and Yaroshevskiy, 1976; Ronov, 1982), though this value is nearly certainly inaccurate. This mass of organic carbon translates to a global marine sediment average of 3.6 dry wt. \% POC (for total volume of marine sediments of $3.01 \times 10^{23} \mathrm{~cm}^{3}$ (LaRowe et al., 2017), a nominal porosity of $50 \%$ and sediment grain density of $2.3 \mathrm{~g} \mathrm{~cm}^{-3}$ ), a massive amount that is rarely found anywhere beyond surface sediments near land masses.

Burdige (2007) calculated that a global carbon $B E$ ranging from 13.4\% to $45.4 \%$ (neither the depth nor the age of burial is specified). Using a benthic model where POC degradation was empirically constrained using a power law, Stolpovsky et al. (2015) determined a global mean $B E$ of $6.1 \pm 3 \%$ for bioturbated Holocene sediments. Burial efficiencies for the baseline, low and high POC reactivity scenarios in the bioturbated Holocene layer determined here are $20 \%, 7.3 \%$ and 

the same three reactivity scenarios. The baseline, low and high POC reactivity scenarios yield burial efficiencies in Pleistocene sediments of $24.4 \%, 11.2 \%$ and $5.7 \%$, respectively. Our $B E$ results are consistent with the range reported by Burdige (2007), and similar to those of Stolpovsky et al. (2015). This is despite the fact that our model makes no concessions for specific factors that can alter the preservation efficiency of POC, such as the mineralogy and surface area of inorganic sedimentary particles and oxygen exposure time (Keil et al., 1994; Mayer, 1994; Hedges et al., 1999). Most likely, the tested ranges of the POC reactivity parameter $i a$ cover a large fraction of the uncertainty associated with these factors. We also did not consider sediment resuspension on the continental margins through the generation of currents and internal waves, which can then be transported up- or downslope (Hosegood and van Haren, 2004; Martini et al., 2013).

\subsection{Microbial degradation of organic carbon}

One of the most important factors determining the size and activity level of a given microbial population is the amount of energy that is available to it and the rate at which this energy is supplied. The rate at which energy is made available in marine sediments, the microbial power supply (see LaRowe and Amend, 2015a), is largely controlled by the rate at which POC is delivered to sediments. Therefore, the rates of POC degraded in bioturbated Holocene, nonbioturbated Holocene and Pleistocene sediments (Table 4) effectively display the rates of microbial activity in sediments down to the depths shown in Fig. 4. For instance, $11.5 \times 10^{13} \mathrm{~g}$ of carbon is degraded in non-bioturbated Holocene sediments per year, with the majority of it (91\%) degraded in shelf sediments. By contrast, only about $6 \%$ of non-bioturbated Holocene POC degradation occurs in abyssal sediments (see Table 4). However, in the Pleistocene layer, these trends are reversed. Furthermore, because the absolute amount of POC that is deposited on continental shelves and margins is far greater than the amount that arrives at the SWI in open ocean settings, the rates and sizes of near-shore sedimentary microbial communities should be far larger than those in the abyss. However, due to different sedimentation patterns in the Pleistocene globally (Figs. 3-4), much more microbial activity is expected in abyssal sediments than margin sediments, with a trivial amount in shelf sediments. This has been substantiated in part by marine sediment cell counts that shows far higher cell densities in near-shore sediments than in those from open ocean sites (Kallmeyer et al., 2012; Parkes et al., 2014; D'Hondt et al., 2015).

The average numbers of heterotrophic microbes calculated to be actively maintained through the degradation of organic carbon in the representative sediment columns shown in Fig. 9b $\left(\sim 10^{4}\right.$ to $10^{-3}$ cells $\left.\mathrm{cm}^{-3}\right)$ are many orders of magnitude lower than cell counts in marine sediments. Cell counts in surface sediments vary between at least $10^{5}$ and $10^{10} \mathrm{cells}^{-3}$ (Kallmeyer et al., 2012; Parkes et al., 2014; D'Hondt et al., 2015), while deeper in a given sediment column, cell numbers typically, but not always (e.g., D'Hondt et al. (2004)) decrease according to a power law (Kallmeyer et al., 2012; Parkes et al., 2014). In coastal sediments tens to hundreds of meters below the SWI, cell counts are typically $10^{6}-10^{8} \mathrm{cells} \mathrm{cm}^{-3}$, while at equivalent sediment depths under oligotrophic waters, cells counts are more likely to vary between $10^{3}$ and $10^{6}$ cells $\mathrm{cm}^{-3}$ (Kallmeyer et al., 2012; D'Hondt et al., 2015). Clearly, the procedures used to estimate biomass in this study do not match reported cell counts.

The values of maintenance power, $P_{d}$, used in Eqn. (29), which are derived from laboratory studies of growing organisms, are thought to be far larger than those of organisms living in relatively low-energy environments (Hoehler and Jørgensen, 2013). In fact, recent studies have shown that when maintenance powers that are two orders of magnitude lower than the lowest 
reported in the literature are used to estimate the number of microbes in very-low energy sediments, the predictions closely match cell counts (LaRowe and Amend, 2015a, b). If we used $P_{d}$ values representative of natural marine sediments, which are constrained by geochemical data and modeling results $\left(0.01 \mathrm{fW}\right.$ cell $^{-1}$ (LaRowe and Amend, 2015a, b), the predicted cell abundances would be five orders of magnitude higher than those shown in Fig. 9b, which are calculated using laboratory-derived $P_{d}$ values. Such estimates are much more in line with cell counts for these types of settings (Kallmeyer et al., 2012). It should be noted that this analysis does not take into account the energetics of growth and/or biomass replacement, which can vary substantially depending on environmental conditions (LaRowe and Amend, 2016). In addition, we do not attempt to account for the number of microorganisms that could be maintaining themselves via fermentation, methanogenesis or chemolithotrophy.

\subsection{Deeper organic carbon}

The discussion of organic carbon thus far has focused on environments for which sedimentation and organic carbon deposition rates are reasonably well-known throughout the Quaternary Period, about $\sim 18 \%$ of the total volume of global marine sediments (LaRowe et al., 2017). That is, sediments older than 2.59 Ma have not been discussed with respect to the amount of microbial biomass contained within them, or their metabolic activity, despite the fact that microbial cells have been found in sediments far older than the Quaternary (D'Hondt et al., 2004; Kallmeyer et al., 2012; D'Hondt et al., 2015) that seem to be active or capable of activity (Schippers et al., 2005; Morono et al., 2011; Engelhardt et al., 2014; Inagaki et al., 2015). Although all three of the POC reactivity scenarios for the Pleistocene considered in this study show that a significant amount of organic carbon has been buried beneath 2.59 Myr-old sediments, the distribution and rates of organic carbon degradation beneath these depths cannot be estimated using the model described in this study without additional information extending further back into the Cenozoic Era.

Despite these limitations, evidence for variations in global organic carbon deposition over geological timescales is abundant (Berner, 2004). Deep marine sediments have prominently recorded seven major climate and carbon cycle perturbations during the Jurassic and Cretaceous periods known as Oceanic Anoxic Events (OAEs, (Jenkyns, 2010), intervals of enhanced global deposition of organic carbon forming black shale layers with POC contents between 2 and $30 \mathrm{wt} \%$. In addition to global events, regional climate change has also enhanced organic carbon deposition in specific ocean regions. For instance, marine sediments in the Mediterranean reveal a quasiperiodic deposition of organic-carbon-rich layers, so-called sapropels, over the last 13.5 million years. Assessing the significance of these paleo-strata for the global sedimentary OC budget and energy availability in the deep biosphere is compromised by the difficulties associated with constraining the spatial and temporal distribution of organic carbon deposition during these times, as well as determining their current burial depth. However, porewater data and inverse modelling can reveal significant changes in the magnitude and quality of organic carbon deposition in some regions, e.g., (Arndt et al., 2006, 2009; Wehrman et al., 2013).

\section{Concluding remarks}

In this study, we presented the most comprehensive quantitative analysis to date of the global distribution and degradation rates of particulate organic carbon in marine sediments The results are reported in terms of ocean provinces based largely on water depth, and temporally in terms of the Holocene and Pleistocene, but the data sets and methods can be used to assess the 
amount of POC in marine sediments at any location or time-period $(\leq 2.59 \mathrm{Ma})$. One such application of this model is the quantification of near-shore carbon stocks for maritime nations as part of climate-mitigation action (Avelar et al., 2017). More specifically, a more advanced version of the model presented here could help predict the fate of POC converted by microbial activity to $\mathrm{CO}_{2}$ vs. $\mathrm{CH}_{4}$, and thus the radiative forcing power of the respired carbon. However, the more profound application of our model is what it reveals about the deep biosphere, a poorly understand but vast window into the limits of life on Earth and perhaps elsewhere.

Simply put, the relatively recent discovery of viable microorganisms deep in marine sediments has changed how scientists view the size and extent of the biosphere. Although there was already a growing consensus that these microorganisms are operating at much lower power levels than their surface analogs (e.g., Hoehler and Jørgensen (2013); LaRowe and Amend (2015a, b)), virtually nothing was known about what these organisms are doing or the rates at which they are active on a global scale. The model results presented in this study help decipher the structure and activity levels of microorganisms in the deep biosphere while revealing the spatial history of organic carbon degradation and burial throughout the Quaternary period. When expressed through a bioenergetic perspective, the rates of organic carbon degradation and burial not only compare well with other estimated values, but correspond with microbial cell densities reported in the literature when appropriately low maintenance powers are used instead of laboratory-determined ones. Instead of just knowing the number of microorganisms living in marine sediments, we can now specify the rates at which they are consuming organic carbon and where they are doing it. As models such as the one presented above are applied to deeper sediments, in conjunction with global-scale data on the occurrence of organic-rich horizons, a more complete descriptions of the deep biosphere and the organic carbon cycle are possible.

\section{Acknowledgements}

This work was supported by the NSF-sponsored Center for Dark Energy Biosphere Investigations (C-DEBI) under grant OCE0939564; NASA Astrobiology Institute - Life Underground (NAI-LU) grant NNA13AA92A; the USC Zumberge Fund Individual Grant; the Alfred P. Sloan Foundation through the Deep Carbon Observatory and the NASA-NSF Origins of Life Ideas Lab program under grant NNN13D466T. This is C-DEBI contribution X and NAI-LU contribution Y (to be assigned if accepted for publication). Sandra Arndt acknowledges support from the European Union Horizon 2020 research and innovation program under the Marie Skłodowska-Curie grant agreement no. 643052 (C-CASCADES).

[References in tables but not in text: (Westrich and Berner, 1984; Wallmann et al., 2006; Marquardt et al., 2010; Mogollon et al., 2012)]

\section{References Cited}

Aris, R. (1968) Prolegomena to the rational analysis of systems of chemical reactions, II. Some adenda. Arch. Rational Mech. Analysis 27, 356-364.

Arndt, S., Brumsack, H.-J. and Wirtz, K.W. (2006) Cretaceous black shales as active bioreactors: A biogeochemical model for the deep biosphere encountered during ODP Leg 207 (Demerara Rise). Geochim. Cosmochim. Acta 70, 408-425.

Arndt, S., Hetzel, A. and Brumsack, H.-J. (2009) Evolution of organic matter degradation in Cretaceous black shales inferred from authigenic barite: A reaction-transport model. Geochim. Cosmochim. Acta 73, 2000-2022. 
Athy, L.F. (1930) Density, porosity and compaction of sedimentary rocks. AAPG Bull. 14, 1-24. Avelar, S., van der Voort, T.S. and Eglington, T.I. (2017) Relevance of carbon stocks of marine sediments for national greenhouse gas inventories of maritime nations. Carbon Balance and Management 12, doi: 10.1186/s13021-13017-10077-x.

Berner, R.A. (1980) Early Diagenesis: A Theoretical Approach Princeton Univ. Press, Princeton, N.J.

Berner, R.A. (2004) The Phanerozoic Carbon Cycle: $\mathrm{CO}_{2}$ and $\mathrm{O}_{2}$. Oxford University Press, Oxford.

Berner, R.A. (2006) GEOCARBSULF: A combine model for Phanerozoic atmospheric $\mathrm{O}_{2}$ and $\mathrm{CO}_{2}$. Geochim. Cosmochim. Acta 70, 5653-5664.

Betts, J.N. and Holland, H.D. (1991) The oxygen content of ocean bottom waters, the burial efficiency or organic carbon, and the regulation of atmospheric oxygen. Palaeogeog. Palaeoclim. Palaeoecol. 97, 5-18.

Boudreau, B.P. (1997) Diagenetic models and their implementation : Modelling transport and reactions in aquatic sediments. Springer, Berlin.

Boudreau, B.P. and Ruddick, B.R. (1991) On a reactive continuum representation of organic matter diagenesis. Amer. J. Sci. 291, 507-538.

Bradley, J.A., Amend, J.P. and LaRowe, D.E. (2018a) Bioenergetic controls on micorbial ecophysiology in marine sediments. Frontiers in Microbiology 9, Article 180.

Bradley, J.A., Amend, J.P. and LaRowe, D.E. (2018b) Microbial dormancy and maintenance in marine sediments through deep time. Geobiology 17, 43-59.

Bradley, J.A., Amend, J.P. and LaRowe, D.E. (2018c) Necromass as a limited source of energy for microorganisms in marine sediments Journal of Geophysical Research: Biogeosciences 123, 577-590.

Burdige, D.J. (2007) Preservation of organic matter in marine sediments: Controls, mechanisms and an imbalance in sediment organic carbon budgets? Chem. Rev. 107, 467-485.

Burwicz, E.B., Rüpke, L.H. and Wallmann, K. (2011) Estimation of the global amount of submarine gas hydrates formed via microbial methane formation based on numerical reaction-transport modeling and a novel parameterization of Holocene sedimentation. Geochim. Cosmochim. Acta 75, 4562-4576.

Canfield, D.E. (1993) Organic matter oxidation in marine sediments, in: R. Wollast, F.T. MacKenzie, L. Chou (Eds.), Interactions of C, N, P and S Biogeochemical Cycles and Global Change. Springer-Verlag, Berlin, pp. 333-363.

Canfield, D.E., Kristensen, E. and Thamdrup, B. (2005) Advances in Marine Biology: Aquatic Geomicrobiology. Elsevier Academic Press, San Diego.

Cogley, J.G. (1984) Continental margins and the extent and number of the continents. Rev. Geophys. Space Phys. 22, 101-122.

Colman, A.S. and Holland, H.D. (2000) The global diagenetic flux of phosphorous from marine sediments to the ocean: redox sensitivity and the control of atmospheric oxygen levels, Marine Authigenesis: From Global to Microbial. Society of Sedimentary Geology.

D'Hondt, S., Inagaki, F., Zarikian, C.A., Abrams, L.J., Dubois, N., Engelhardt, T., Evans, H., Ferdelman, T., Gribsholt, B., Harris, R., Hoppie, B.W., Hyun, J.-H., Kallmeyer, J., Kim, J., Lynch, J.E., McKinley, C.C., Mitsunobu, S., Morono, Y., Murray, R.W., Pockalny, R., Sauvage, J., Shimono, T., Shiraishi, F., Smith, D.C., Smith-Duque, C.E., Spivack, A.J., Steinsbu, B.O., Suzuki, Y., Szpak, M., Toffin, L., Uramoto, G., Yamaguchi, Y.T., Zhang, 
G., Zhang, X.-H. and Ziebis, W. (2015) Presence of oxygen and aerobic communities from sea floor to basement in deep-sea sediments. Nat. Geosci. 8, 299-304.

D'Hondt, S., Jørgensen, B.B., Miller, D.J., Batzke, A., Blake, R., Cragg, B.A., Cypionka, H., Dickens, G.R., Ferdelman, T., Hinrichs, K.U., Holm, N.G., Mitterer, R., Spivack, A., Wang, G.Z., Bekins, B., Engelen, B., Ford, K., Gettemy, G., Rutherford, S.D., Sass, H., Skilbeck, C.G., Aiello, I.W., Guerin, G., House, C.H., Inagaki, F., Meister, P., Naehr, T., Niitsuma, S., Parkes, R.J., Schippers, A., Smith, D.C., Teske, A., Wiegel, J., Padilla, C.N. and Acosta, J.L.S. (2004) Distributions of microbial activities in deep subseafloor sediments. Science 306, 2216 - 2221.

Dale, A.W., Boyle, R.A., Lenton, T.M., Ingall, E.D. and Wallmann, K. (2016) A model for microbial phosphorus cycling in bioturbated marine sediments: Significance for phosphorus burial in the early Paleozoic. Geochimica et Cosmochimica Acta 189, 251268.

Dale, A.W., Nickelsen, L., Scholz, F., Hensen, C., Oschlies, A. and Wallmann, K. (2015) A revised global estimate of dissolved iron fluxes from marine sediments. Global Biogeochemical Cycles 29, 691-707.

Eakins, B.W. and Sharman, G.F. (2010) Volumes of the World's Oceans from ETOPO1. NOAA National Geophysical Data Center, Boulder, CO.

Eglington, T.I. and Repeta, D.J. (2014) Organic matter in the contemporary ocean, in: Turekian, K.K., Holland, H.D. (Eds.), Treatise on Geochemistry, 2 ed. Elsevier, Amsterdam, pp. 151-189.

Emerson, S. and Bender, M. (1981) Carbon fluxes at the sediment-water interface of the deepsea - calcium carbonate preservation. J. Mar. Res. 39, 139-162.

Engelhardt, T., Kallmeyer, J., Cypionka, H. and Engelen, B. (2014) High virus-to-cell ratios indicate ongoing productino of viruses in deep subsurface sediments. ISME J. 8, 15031509.

Freitas, F.S., Pancost, R.D. and Arndt, S. (2017) The impact of alkeone degradation on $\mathrm{U}^{\mathrm{K}} 37$ paleothermometry: A model-derived assessment. Paleoceanography 32, 648-672.

Glombitza, C., Jaussi, M. and Røy, H. (2015) Formate, acetate, and propionate as substrates for sulfate reduction in sub-arctic sediments of Southwest Greenland. Frontiers in Microbiology 6: 846, doi.org/10.3389/fmicb.2015.00846.

Hantschel, T. and Kauerauf, A.I. (2009) Fundamentals of Basin and Petroleum Systems Modeling. Springer-Verlag, Berlin.

Hay, W.W. (1994) Pleistocene-Holocene fluxes are not the Earth's norm, in: Hay, W.W., Usselman, T. (Eds.), Material Fluxes on the Surface of the Earth. National Academy Press, Washington D.C., pp. 15-27.

Hedges, J.I. (1992) Global biogeochemical cycles: progress and problems. Mar. Chem. 39, 6793.

Hedges, J.I., Hu, F.S., Devol, A.H., Hartnett, H.E., Tsamakis, E. and Keil, R.G. (1999) Sedimentary organic matter preservation: A test for selective degradation under oxic conditions. American Journal of Science 299, 529-555.

Hedges, J.I. and Oades, J.M. (1997) Comparative organic geochemistries of soils and marine sediments. Org. Geochem. 27, 319-361.

Helgeson, H.C. (1969) Thermodynamics of hydrothermal systems at elevated temperatures and pressures. Amer. J. Sci. 267, 729-804. 
Helgeson, H.C., Kirkham, D.H. and Flowers, G.C. (1981) Theoretical prediction of thermodynamic behavior of aqueous electrolytes at high pressures and temperatures: 4 . Calculation of activity coefficients, osmotic coefficients, and apparent molal and standard and relative partial molal properties to $600^{\circ} \mathrm{C}$ and $5 \mathrm{~kb}$. Amer. J. Sci. 281, $1249-1516$. Ho, T.C. and Aris, R. (1987) On apparent second-order kinetics Amer. Inst. Chem. Eng. J. 33, 1050-1051.

Hoehler, T.M. and Jørgensen, B.B. (2013) Micorbial life under extreme energy limitation. Nat. Rev. Microbiol. 11, 83-94.

Hosegood, P. and van Haren, H. (2004) Near-bed solibores over the continental slope in the Faeroe-Shetland Channel. Deep-Sea Research II 51, 2943-2971.

Inagaki, F., Hinrichs, K.-U., Kubo, Y., Bowles, M.W., Heuer, V.B., Hong, W.-L., Hoshino, T., Ijiri, A., Imachi, H., Ito, M., Kaneko, M., Lever, M.A., Lin, Y.-S., Methé, B.A., Morita, S., Morono, Y., Tanikawa, W., Bihan, M., Bowden, S.A., Elvert, M., Glombitza, C., Gross, D., Harrington, G.J., Hori, T., Li, K., Limmer, D., Liu, C.-H., Murayama, M., Ohkouchi, N., Ono, S., Park, Y.-S., Phillips, S.C., Prieto-Mollar, X., Purkey, M., Riedinger, N., Sanada, Y., Sauvage, J., Snyder, G., Susilawati, R., Takano, Y., Tasumi, E., Terada, T., Tomaru, H., Trembath-Reichert, E., Wang, D.T. and Yamada, Y. (2015) Exploring deep microbial life in coal-bearing sediment down to $\sim 2.5 \mathrm{~km}$ below the ocean floor. Science 349, 420-424.

Jenkyns, H.C. (2010) Geochemistry of oceanic anoxic events. Geochem. Geophys. Geosys. 11, Q03004 doi:03010.01029/02009GC002788.

Johnson, J.W., Oelkers, E.H. and Helgeson, H.C. (1992) SUPCRT92 - A software package for calculating the standard molal thermodynamic properties of minerals, gases, aqueous species, and reactions from 1 bar to 5000 bar and $0^{\circ} \mathrm{C}$ to $1000^{\circ} \mathrm{C}$. Comput. Geosci. 18, 899 - 947.

Jørgensen, B.B. and Kasten, S. (2006) Sulfur cycling and methane oxidation, in: Schulz, H.D., Zabel, M. (Eds.), Marine Geochemistry, 2nd ed. Springer, Berlin, pp. 271-308.

Kallmeyer, J., Pockalny, R., Adhikari, R.R., Smith, D.C. and D'Hondt, S. (2012) Global distribution of microbial abundance and biomass in subseafloor sediment. PNAS 109, $16213-16216$.

Keil, R.G., Montlucon, D.B., Prahl, F.G. and Hedges, J.I. (1994) Sorptive presevation of labile organic matter in marine sediments. Nature 370, 549-552.

LaRowe, D.E. and Amend, J.P. (2015a) Catabolic rates, population sizes and doubling/replacement times of microorganisms in the natural settings. Am. J. Sci. 315, 167-203.

LaRowe, D.E. and Amend, J.P. (2015b) Power limits for microbial life. Front. Extr. Microbiol. 6, Article 718 doi: $710.3389 /$ fmicb. 2015.00718

LaRowe, D.E. and Amend, J.P. (2016) The energetics of anabolism in natural settings. ISME J. 10, 1285-1295.

LaRowe, D.E., Burwicz, E.B., Arndt, S., Dale, A.W. and Amend, J.P. (2017) The temperature and volume of global marine sediments. Geology 45, 275-278.

Lisitzin, A.P. (1996) Oceanic Sedimentation: Lithology and Geochemistry. American Geophysical Union, Washington D.C.

Ludwig, W., Amiotte-Suchet, P. and Probst, J.L. (1999) Enhanced chemical weathering of roacks during the last glacial maximum: A sink for atmospheric $\mathrm{CO}_{2}$ ? Chemical Geology 159, $147-161$. 
933

934

935

936

937

938

939

940

941

942

943

944

945

946

947

948

949

950

951

952

953

954

955

956

957

958

959

960

961

962

963

964

965

966

967

968

969

970

971

972

973

974

975

976

977

Marquardt, M., Hensen, C., Piñero, E., Wallmann, K. and Haeckel, M. (2010) A transfer function for the prediction of gas hydrate inventories in marine sediments Biogeosciences 7, 2925-2941.

Martini, K.I., Alford, M.H., Kunze, E., Kelly, S.M. and Nash, J.D. (2013) Internal bores and breaking internal tides on the Orgeon continental slope. Journal of Physical Oceanography 43, 120-139.

Mayer, L.M. (1994) Surface area control of organic carbon accumulation in continental shelf sediments. Geochim. Cosmochim. Acta 58, 1271-1284.

Meile, C. and Van Cappellen, P. (2005) Particle age distriutions and $\mathrm{O}_{2}$ exposure times: Timescales in bioturbated sediments Global Biogeochemical Cycles 19, Article GB3013.

Menard, H.W. and Smith, S.M. (1966) Hypsometry of ocean basin provinces. J. Geophys. Res. 71, 4305-4325.

Middelburg, J.J. (1989) A simple rate model for organic matter decomposition in marine sediments. Geochem. Cosmochim. Acta 53, 1577-1581.

Middelburg, J.J., Soetaert, K. and Herman, M.J.H. (1997) Empirical relationships for use in global diagenetic models. Deep-Sea Res. I 44, 327-344.

Mogollon, J.M., Dale, A.W., Fossing, H. and Regnier, P. (2012) Timescales for the development of methanogenesis and free gas layers in recently-deposited sediments of Arkona Bason (Baltic Sea). Biogeosciences 9, 1915-1933.

Morono, Y., Terada, T., Nishizawa, M., Ito, M., Hillion, F., Takahata, N., Sano, Y. and Inagaki, F. (2011) Carbon and nitrogen assimilation in deep subseafloor micorbial cells. PNAS 108, 18295-18300.

Parkes, R.J., Cragg, B., Roussel, E., Webster, G., Weightman, A. and Sass, H. (2014) A review of prokaryotic populations and processes in sub-seafloor sediments, including biosphere:geosphere interactions. Mar. Geol. 352, 409-425.

Peltier, W.R. (1994) Ice age paleotopography. Science 265, 195-201.

Rohling, E.J., Fenton, M., Jorissen, F.J., Bertrand, P., Ganssen, G. and Caulet, J.P. (1998) Magnitudes of sea-level lowstands of the past 500,000 years. Nature 394, 162-165.

Romankevich, E.A., Vetrov, A.A. and Peresypkin, V.I. (2009) Organic matter of the world ocean. Russ. Geol. Geophys. 50, 299-307.

Ronov, A.B. (1982) The Earth's sedimentary shell. International Geology Reviews 24, 13131388.

Ronov, A.B. and Yaroshevskiy, A.A. (1976) A new model for the chemical structure of the Earth's crust. Geochemistry International 13, 89-121.

Rothman, D.H. (2002) Atmospheric carbon dioxide levels for the last 500 million years. PNAS 99, 4167-4171.

Røy, H., Kallmeyer, J., Adhikari, R.R., Pockalny, R., Jørgensen, B.B. and D'Hondt, S. (2012) Aerobic microbial respiration in 86-million-year-old deep-sea red clay. Science 336, 922 925.

Schippers, A., Neretin, L.N., Kallmeyer, J., Ferdelman, T.G., Cragg, B.A., Parkes, R.J. and Jørgensen, B.B. (2005) Prokaryotic cells of the deep sub-seafloor biosphere identified as living bacteria. Nature 433, 861 - 864.

Schulte, M.D., Shock, E.L. and Wood, R. (2001) The temperature dependence of the standardstate thermodynamic properties of aqueous nonelectrolytes. Geochim. Cosmochim. Acta 65, 3919 - 3930 . 
978

979

980

981

982

983

984

985

986

987

988

989

990

991

992

993

994

995

996

997

998

999

1000

1001

1002

1003

1004

1005

1006

1007

1008

1009

1010

1011

1012

1013

1014

1015

1016

1017

1018

1019

1020

1021

Seiter, K., Hensen, C., Schroter, J. and Zabel, M. (2004) Organic carbon content in surface sediments - defining regional provinces. Deep-Sea Res. I 51, 2001-2026.

Shock, E.L. and Helgeson, H.C. (1988) Calculation of the thermodynamic and transport properties of aqueous species at high pressures and temperatures - Correlation algorithms for ionic species and equation of state predictions to $5 \mathrm{~kb}$ and $1000^{\circ} \mathrm{C}$. Geochim. Cosmochim. Acta 52, 2009 - 2036.

Shock, E.L. and Helgeson, H.C. (1990) Calculation of the thermodynamic and transport properties of aqueous species at high pressures and temperatures - Standard partial molal properties of organic species. Geochim. Cosmochim. Acta 54, 915 - 945.

Shock, E.L., Helgeson, H.C. and Sverjensky, D. (1989) Calculation of the thermodynamic and transport properties of aqueous species at high pressures and temperatures - Standard partial molal properties of inorganic neutral species. Geochim. Cosmochim. Acta 53, $2157-2183$.

Shock, E.L., Oelkers, E., Johnson, J., Sverjensky, D. and Helgeson, H.C. (1992) Calculation of the thermodynamic properties of aqueous species at high pressures and temperatures Effective electrostatic radii, dissociation constants and standard partial molal properties to $1000^{\circ} \mathrm{C}$ and 5 kbar. J. Chem. Soc. Faraday Trans. 88, 803 - 826.

Stolpovsky, K., Dale, A.W. and Wallmann, K. (2015) Toward a prameterization of global-scale organic carbon mineralization kinetics in surface marine sediments. Global Biogeochemical Cycles 29, 812-829.

Stolpovsky, K., Dale, A.W. and Wallmann, K. (2018) A new look at the multi-H model for organic carbon degradation in surface marine sediments for coupled benthic-pelagic simulations of the global ocean. Biogeosciences 15, 3391-3407.

Sverjensky, D., Shock, E.L. and Helgeson, H.C. (1997) Prediction of the thermodynamic properties of aqueous metal complexes to $1000^{\circ} \mathrm{C}$ and $5 \mathrm{~kb}$. Geochim. Cosmochim. Acta 61, $1359-1412$.

Tanger, J.C. and Helgeson, H.C. (1988) Calculation of the thermodynamic and transport properties of aqueous species at high pressures and temperatures - Revised equations of state for the standard partial molal properties of ions and electrolytes. Amer. J. Sci. 288, $19-98$.

Thullner, M., Dale, A.W. and Regnier, P. (2009) Global-scale quantification of mineralization pathways in marine sediments: A reaction-transport modeling approach. Geochem. Geophys. Geosys. 10, 1-24.

Tromp, T.K., Van Cappellen, P. and Key, R.M. (1995) A global model for the early diagenesis of organic carbon and organic phosphorous in marine sediments. Geochim. Cosmochim. Acta 59, 1259-1284.

Vion, A. and Menot, L. (2009) Continental margins between 140m and 3500m depth., http://www.marineregions.org/ IFREMER.

Wadham, J.L., De'Ath, R., Monteiro, F.M., Tranter, M., Ridgwell, A., Raiswell, R. and Tulaczyk, S. (2013) The potential role of the Antarctic Ice Sheet in global biogeochemical cycles. Earth and Environmental Science Transactions of the Royal Society of Edinburgh 104, 55-67.

Walker, J.C.G., Hays, P.B. and Kasting, J.F. (1981) A negative feedback mechanism for the long-term stabilization of Earth's surface temperature. J. Geophys. Res. 86, 9776-9782. 
1022

1023

1024

1025

1026

1027

1028

1029

1030

1031

1032

1033

1034

1035

1036

1037

1038

1039

1040

1041

1042

1043

1044

1045

1046

1047

1048

1049

1050

1051

1052

1053

1054

1055

1056

1057

1058

1059

1060

1061

1062

1063

1064

1065

1066

1067
Wallmann, K., Aloisi, G., Haeckel, M., Obzhirov, A., Pavlova, G. and Tishchenko, P. (2006) Kinetics of organic matter degradation, microbial methane generation, and gas hydrate formation in anoxic marine sediments Geochimica et Cosmochimica Acta 70, 3905-3927. Wallmann, K., Pinero, E., Burwicz, E.B., Haeckel, M., Hensen, C., Dale, A.W. and Ruepke, L. (2012) The global inventory of methane hydrate in marine sediments: a theoretical approach. Energies 5, 2449-2498.

Wehrmann, L.M., Arndt, S., März, C., Ferdelman, T.G. and Brunner, B. (2013) The evolution of early diagenetic signals in Bering Sea subseafloor sediments in reponse to varying organic carbon deposition over the last 4.3 Ma. Geochim. Cosmochim. Acta 109, 175196.

Westrich, J.T. and Berner, R.A. (1984) The role of sedimentary organic matter in bacterial sulfate reduction: The G model tested. Limnol. Oceanogr. 29, 236-249.

Whitman, W.B., Coleman, D.C. and Wiebe, W.J. (1998) Prokaryotes: The unseen majority. Proc. Nat. Acad. Sci. USA 95, 6578 - 6583.

Zonneveld, K.A.F., Versteegh, G.J.M., Kasten, S., Eglington, T.I., Emeis, K.-C., Huguet, C., Koch, B.P., de Lange, G.J., de Leeuw, J.W., Middelburg, J.J., Mollenhauer, G., Prahl, F.G., Rethmeyer, J. and Wakeham, S.G. (2010) Selective preservation of organic matter in marine environments; processes and impact on the sedimentary record. Biogeosciences 7, 473-511.

\section{Figure Captions}

Figure 1. Schematic structure of the model domain. For every grid cell in the model $\left(0.25^{\circ} \times\right.$ $0.25^{\circ}$ ) there is a distinct sedimentation rate, $\omega$, and concentration of particulate organic carbon at the sediment water interface (SWI), $P O C_{0}$. The bioturbated Holocene layer is $10 \mathrm{~cm}$ thick (i.e., $\left.z_{b i o}\right)$ in every grid cell, whereas the thicknesses of the non-bioturbated Holocene $\left(z_{\text {holo }}\right)$ and Pleistocene $\left(z_{\text {pleis }}\right)$ layers are variable, depending on sedimentation rates, as indicated by the differing total depths of sediment columns $a$ and $b$. Sediments at the bottom of the non-bioturbated Holocene layer are 11,700 years old. In some locations, sediments at the bottom of the Pleistocene layer are 2.59 Myrs old, the beginning of this Epoch. In locations where the seafloor is not that old, or where seawater did not cover continental shelves during that Epoch, sediments at the bottom of the Pleistocene layer are less than 2.59 Myrs old (see Fig. 4).

Figure 2. Illustration of the shelf, margin and abyss domains considered in this study. The location of the continental margin boundaries was adopted from Vion and Menot (2009): shelf environments (white) roughly correspond to water depths $<200 \mathrm{~m}$, with the exception of the Antarctic region where shelf area corresponds to water depths $<500 \mathrm{~m}$; areas deeper than $\sim 3500$ $\mathrm{m}$ are taken to be abyssal plain (dark blue). The light blue regions correspond to the continental margin.

Figure 3. Ages of sediment at the bottom of the Pleistocene sediment layer that are less than 2.59 million years. White areas indicate locations where sediments have been deposited at least since the beginning of the Pleistocene, whereas the other colors correspond parts of the ocean floor where the oldest Pleistocene sediments are younger than 2.59 Myrs.

Figure 4. Maximum depths to which (a) Holocene and (b) Pleistocene sediments reach (note 
1068

1069

1070

1071

1072

1073

1074

1075

1076

1077

1078

1079

1080

1081

1082

1083

1084

1085

1086

1087

1088

1089

1090

1091

1092

1093

1094

1095

1096

1097

1098

1099

1100

1101

1102

1103

1104

1105

1106

1107

1108

1109

1110

1111

1112

different scale bars). (c) Total volumes of bioturbated Holocene, non-bioturbated Holocene and Pleistocene sediments and how these volumes are partitioned onto the shelf, slope and abyss domains.

Figure 5. Burial efficiencies, $B E$, of particulate organic carbon, POC, through the bioturbated Holocene (a, d, g) non-bioturbated Holocene (b, e, h) and Pleistocene (c, f, i) sediment layers for the baseline (a-c), low (d-f) and high (g-i) POC reactivity scenarios considered in this study. The values of $B E$ are given as the percent of POC that has fluxed through a given sediment age relative to the depositional flux through the sediment water interface (see Eqs. 20-22).

Figure 6. Integrated masses of particulate organic carbon, $P O C$, preserved $(\overline{P O C})$ in (a) the bioturbated Holocene, (b) non-bioturbated Holocene and (c) Pleistocene sediments layers for the baseline POC reactivity scenario.

Figure 7. Integrated rates of particulate organic carbon, POC, degradation $(\bar{R})$ in (a) the bioturbated Holocene, (b) non-bioturbated Holocene and (c) Pleistocene sediments layers for the baseline POC reactivity scenario.

Figure 8. Rates of particulate organic carbon, POC, degradation in sediments deposited at the beginnings of the (a) Holocene and (b) Pleistocene for the baseline POC reactivity scenario.

Figure 9. a) Power available and b) biomass that could be supported on maintenance power from particulate organic carbon, POC, degradation in sediment columns that are representative of the shelf, margin and abyss domains. The sedimentation rates $(\omega)$, sediment water interface, SWI, porosities $\left(\phi_{0}\right)$, compactions length scales $\left(c_{0}\right)$, POC reactive continuum $i a$ and $v$ parameters, SWI POC contents $\left(P O C_{0}\right)$ and bioturbation coefficients $\left(D_{b}\right)$ used for these domains are given in order of shelf, margin, abyss as follows: $\omega\left(0.04,0.006145,0.000589 \mathrm{~cm} \mathrm{yr}^{-1}\right), \phi_{0}(0.45,0.74,0.7), c_{0}$ $\left(0.0005,0.00017,0.00085 \mathrm{~m}^{-1}\right)$, ia $(52.59,1816,2184 \mathrm{yr}), v(0.125), P O C_{0}(2,1,0.5 \mathrm{wt} \%)$ and $D_{b}$ $\left(27.5,5.54,0.311 \mathrm{~cm}^{2} \mathrm{yr}^{-1}\right)$.

\section{Table Captions}

Table 1. Selected values of parameters used to characterize the porosity and organic carbon content of continental shelf, margin and abyss domains of global marine sediments.

Table 2. Flux of particulate organic carbon (POC) through the sediment water interface (SWI), bioturbated Holocene, non-bioturbated Holocene and Pleistocene sediment layers in the baseline and low and high POC reactivity scenarios considered in this study. Burial efficiencies $(B E)$, calculated as shown in Eq. (26), are also given.

Table 3. Storage of particulate organic carbon, POC, in the bioturbated Holocene, non-bioturbated Holocene and Pleistocene layers in the baseline and low and high POC reactivity scenarios considered in this study. 
1113 Table 4. Rates of particulate organic carbon, POC, degradation in the bioturbated Holocene, non1114 bioturbated Holocene and Pleistocene layers in the baseline and low and high POC reactivity 1115 scenarios considered in this study. 
Table 1

Table 1. Selected values of parameters used to characterize the porosity and organic carbon content of continental shelf, margin and abyss domains of marine sediments

\begin{tabular}{|c|c|c|c|c|c|}
\hline parameter & Definition & Shelf & Margin & Abyss & units \\
\hline \multirow[t]{2}{*}{$\phi_{0}$} & sediment porosity at the & $0.45^{\mathrm{a}}$ & $0.74^{\mathrm{a}, \mathrm{b}}$ & $0.7^{\mathrm{a}}$ & $(-)$ \\
\hline & sediment-water interfeace ${ }^{a}$ & & & & \\
\hline \multirow[t]{2}{*}{$c_{0}$} & sediment compaction & $0.5 \times 10^{-3 a}$ & $1.7 \times 10^{-4 a, b}$ & $0.85 \times 10^{-3 a}$ & $m^{-1}$ \\
\hline & length scale $e^{b}$ & & & & \\
\hline \multirow[t]{4}{*}{ ia } & \multicolumn{4}{|c|}{ reactive continuum age parameter } & $\mathrm{yr}$ \\
\hline & baseline & & $10^{(3.35-14.81 \cdot \omega) c}$ & & \\
\hline & low reactivity & $5^{d}$ & $3 \times 10^{3 \mathrm{e}}$ & $3.5 \times 10^{4 f}$ & \\
\hline & high reactivity & $3 \times 10^{-4 \mathrm{~g}}$ & $3 \times 10^{-4 g}$ & $20^{\mathrm{h}}$ & \\
\hline \multirow[t]{4}{*}{$v$} & \multicolumn{4}{|c|}{ reactive continuum distribution parameter } & $(-)$ \\
\hline & baseline & 0.125 & 0.125 & 0.125 & \\
\hline & low reactivity & $0.135^{d}$ & $0.16^{\mathrm{e}}$ & $0.16^{f}$ & \\
\hline & high reactivity & $0.125^{\mathrm{g}}$ & $0.125^{\mathrm{g}}$ & $0.16^{\mathrm{h}}$ & \\
\hline
\end{tabular}

${ }^{\mathrm{a}}$ These values are representative of a sandstone-siltstone mixture (shelf), a sandstone-siltstoneshale combination (margin) and typical shales and biogenic-dominated sediments (abyss) (Hantschel \& Kauerauf, 2009); ${ }^{b}$ Wallmann et al. (2012); ${ }^{c}$ based on global compilation by Arndt et al. (2013), $\omega$ represents sedimentation rate, $\mathrm{cm} \mathrm{yr}^{-1}$; ${ }^{\mathrm{d}}$ Mogollon et al. (2012), Arkona Basin; ${ }^{\mathrm{e}}$ Wallmann et al. (2006), Sea of Okhotsk; ${ }^{\mathrm{f}}$ Middelburg et al. (1989), Central Pacific; ${ }^{\mathrm{g}}$ Boudreau and Ruddick (1991) \& Westrich and Berner (1984), fresh plankton material from Long Island

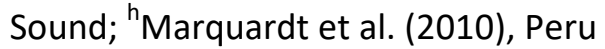


Table 2. Flux of particulate organic carbon (POC) through the sediment water interface (SWI), bioturbated Holocene, non-bioturbated Holocene and Pleistocene sediment layers in the baseline and low and high POC reactivity scenarios considered in this study. Note that the flux of POC through the SWI for the Pleistocene is differnet than the Holocene. Burial efficiences (BE), calculated as shown in Eq.(26), are also given.

\begin{tabular}{|c|c|c|c|c|c|c|}
\hline \multirow{2}{*}{$\begin{array}{c}\text { reactivty scenario: } \\
\text { flux units are } 10^{13}{\mathrm{~g} \mathrm{C} \mathrm{yr}^{-1}}\end{array}$} & \multicolumn{2}{|c|}{ baseline } & \multicolumn{2}{|c|}{ low } & \multicolumn{2}{|c|}{ high } \\
\hline & flux & $B E(\%)$ & flux & $B E(\%)$ & flux & $B E(\%)$ \\
\hline \multicolumn{7}{|l|}{ SWI (Bioturb. \& Holocene) } \\
\hline Shelf & 138 & - & 383 & - & 27,900 & - \\
\hline Margin & 10.2 & - & 8.54 & - & 11,500 & - \\
\hline Abyss & 16.0 & - & 6.67 & - & 105 & - \\
\hline Total & 164 & - & 398 & - & 39,500 & - \\
\hline \multicolumn{7}{|l|}{ Bioturbated Holocene layer } \\
\hline Shelf & 26.8 & 19.5 & 22.8 & 6.0 & 7.24 & 0.026 \\
\hline Margin & 1.85 & 18.1 & 1.86 & 21.8 & 0.40 & 0.004 \\
\hline Abyss & 4.16 & 26.0 & 4.42 & 66.3 & 2.56 & 2.43 \\
\hline Total & 32.8 & 20.0 & 29.1 & 7.3 & 10.2 & 0.03 \\
\hline \multicolumn{7}{|c|}{ Non-bioturbated Holocene layer } \\
\hline Shelf & 14.5 & 10.6 & 10.2 & 2.7 & 3.27 & 0.012 \\
\hline Margin & 1.40 & 13.8 & 1.48 & 17.3 & 0.21 & 0.002 \\
\hline Abyss & 3.41 & 21.3 & 4.27 & 64.1 & 1.61 & 1.53 \\
\hline Total & 19.4 & 11.8 & 15.9 & 4.0 & 5.09 & 0.01 \\
\hline \multicolumn{7}{|l|}{ SWI (Pleistocene) } \\
\hline Shelf & 2.57 & - & 4.23 & - & 27,900 & - \\
\hline Margin & 12.6 & - & 11.3 & - & 11,500 & - \\
\hline Abyss & 24.8 & - & 17.4 & - & 110 & - \\
\hline Total & 40.0 & - & 32.9 & - & 39,500 & - \\
\hline \multicolumn{7}{|l|}{ Pleistocene layer } \\
\hline Shelf & 0.0077 & 0.3 & 0.0049 & 0.1 & 2.63 & 0.010 \\
\hline Margin & 2.96 & 23.5 & 2.58 & 22.8 & 0.43 & 0.004 \\
\hline Abyss & 6.78 & 27.3 & 8.63 & 49.6 & 2.63 & 2.39 \\
\hline Total & 9.75 & 24.4 & 11.2 & 34.1 & 5.70 & 0.01 \\
\hline
\end{tabular}

The depth of the bioturbated layer is set to $10 \mathrm{~cm}$, but the depths of the Holocene and Pleistocene layers are based on their ages and are therefore variable (see Fig. 4). 
$\overline{\text { Table 3. Storage of particulate organic carbon, POC, in the bioturbated Holocene, }}$ non-bioturbated Holocene, and Pleistocene layers in the baseline and low and high reactivity scenarios considered in this study.

\begin{tabular}{lccc}
\hline \multicolumn{1}{c}{ units are $\mathbf{1 0}^{17} \mathbf{g ~ C}$} & baseline & low reactivity & high reactivity \\
\hline $\begin{array}{l}\text { Bioturbated Holocene layer } \\
\text { Shelf }\end{array}$ & 0.25 & 0.23 & 0.10 \\
Margin & 0.20 & 0.20 & 0.06 \\
Abyss & 1.23 & 1.27 & 0.95 \\
Total & 1.68 & 1.70 & 1.11 \\
Non-bioturbated Holocene layer & & \\
Shelf & 19.30 & 13.70 & 4.34 \\
Margin & 1.93 & 2.02 & 0.30 \\
Abyss & 5.17 & 6.23 & 2.52 \\
Total & 26.40 & 21.95 & 7.16 \\
Pleistocene layer & & & \\
Shelf & 0.51 & 0.33 & 0.11 \\
Margin & 423.7 & 391.3 & 61.35 \\
Abyss & 997.6 & 1320 & 400.5 \\
Total & 1422 & 1711 & 461.9 \\
\hline
\end{tabular}

The depth of the bioturbated layer is fixed at $10 \mathrm{~cm}$, but the depths of the Holocene and Pleistocene layers are based on their ages and are therefore variable (see Fig. 4). 
Table 4. Rates of particulate organic carbon, POC, degradation in the bioturbated, Holocene, non-bioturbated Holocene and Pleistocene layers in the baseline and low and high POC reactivity scenarios considered in this study.

\begin{tabular}{lccc}
\hline units are $1 \mathbf{1 0}^{\mathbf{1 3}} \mathbf{g ~ C ~} \mathbf{~ r ~}^{-1}$ & baseline & low reactivity & high reactivity \\
\hline Bioturbated Holocene Layer & & & \\
$\quad$ Shelf & 5.93 & 41.91 & 15,190 \\
Margin & 0.16 & 0.10 & 6,297 \\
Abyss & 0.67 & 0.06 & 35.68 \\
$\quad$ Total & 6.76 & 42.07 & 21,523 \\
Non-bioturbated Holocene layer & & \\
Shelf & 10.42 & 11.25 & 3.56 \\
Margin & 0.35 & 0.29 & 0.18 \\
Abyss & 0.74 & 0.16 & 1.00 \\
Total & 11.51 & 11.70 & 4.74 \\
Pleistocene layer & & & \\
Shelf & 0.01 & 0.01 & 0.002 \\
Margin & 3.89 & 4.31 & 1.08 \\
Abyss & 7.91 & 6.56 & 7.07 \\
Total & 11.81 & 10.87 & 8.15 \\
\hline
\end{tabular}

The depth of the bioturbated layer is set to $10 \mathrm{~cm}$, but the depths of the Holocene and Pleistocene layers are based on their ages and are therefore variable (see Fig. 4). 
Figure 1

Figure 1.

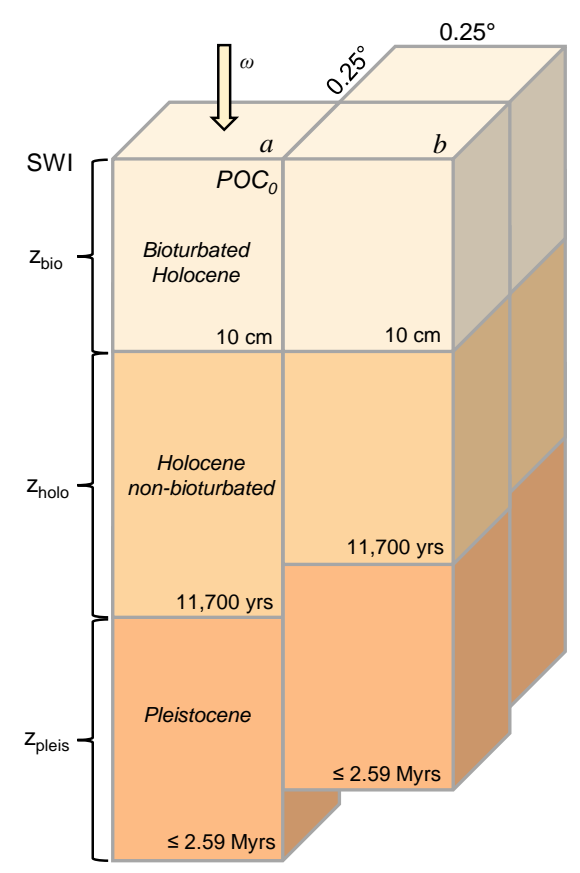


Figure 2

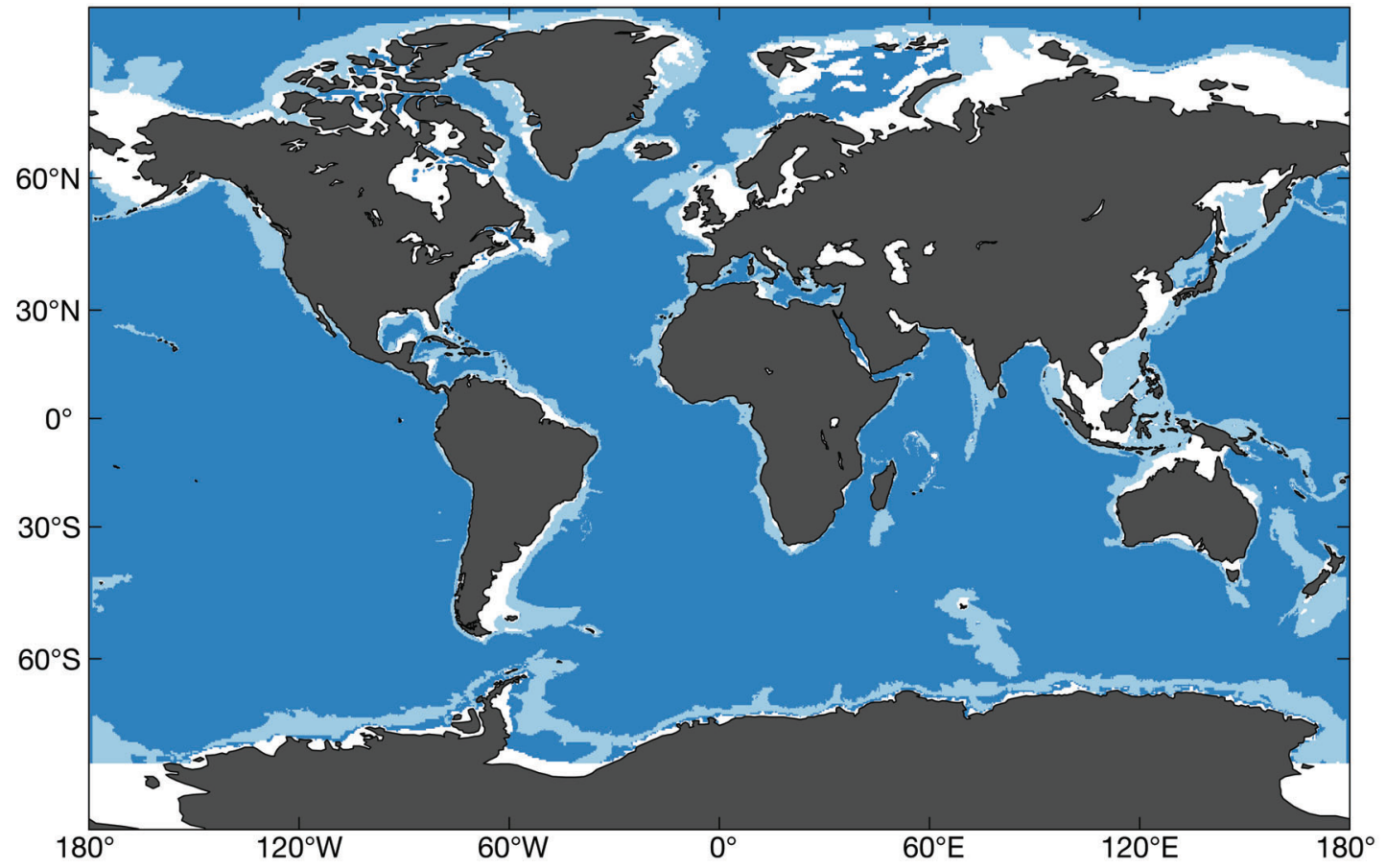


Figure 3

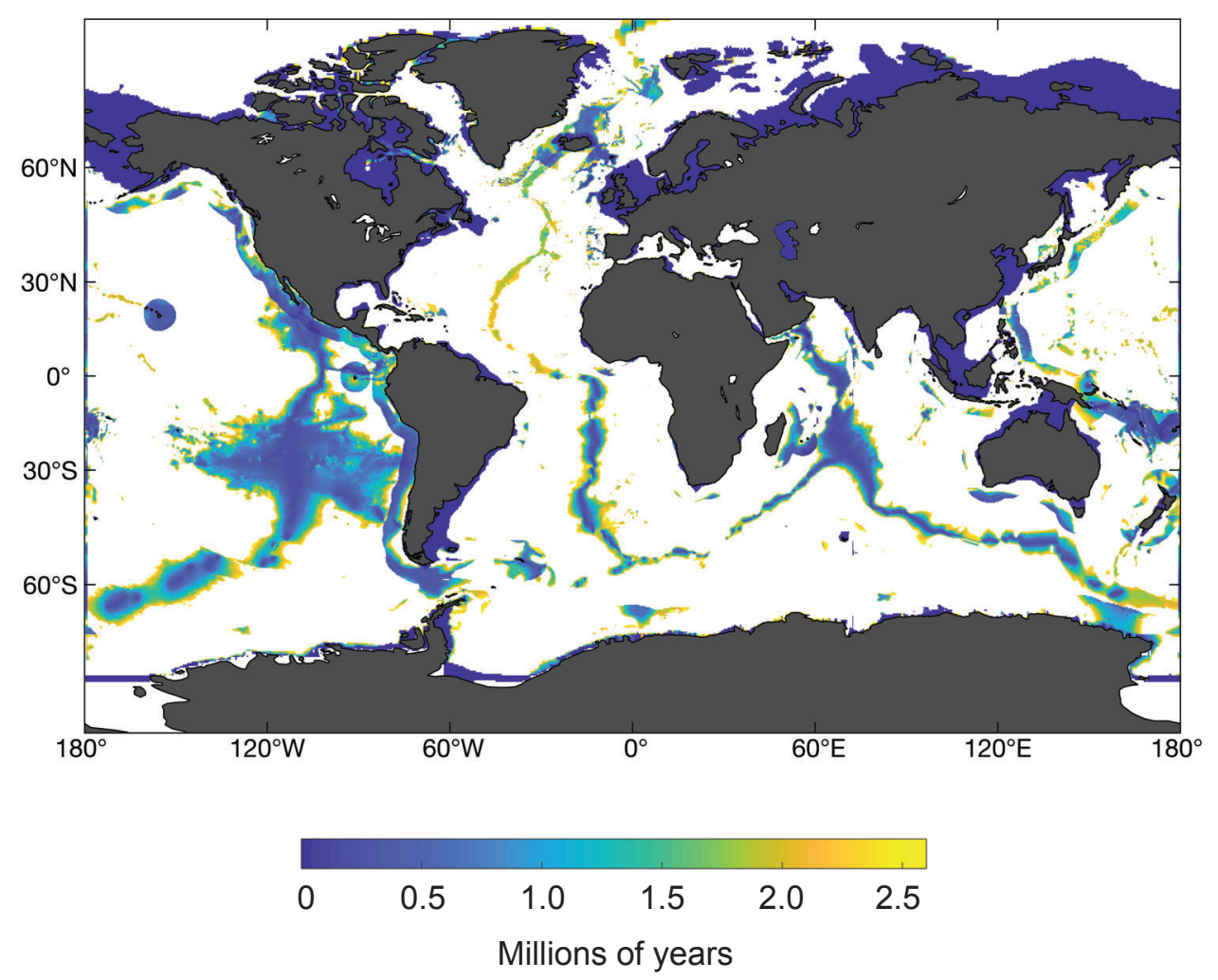


a)

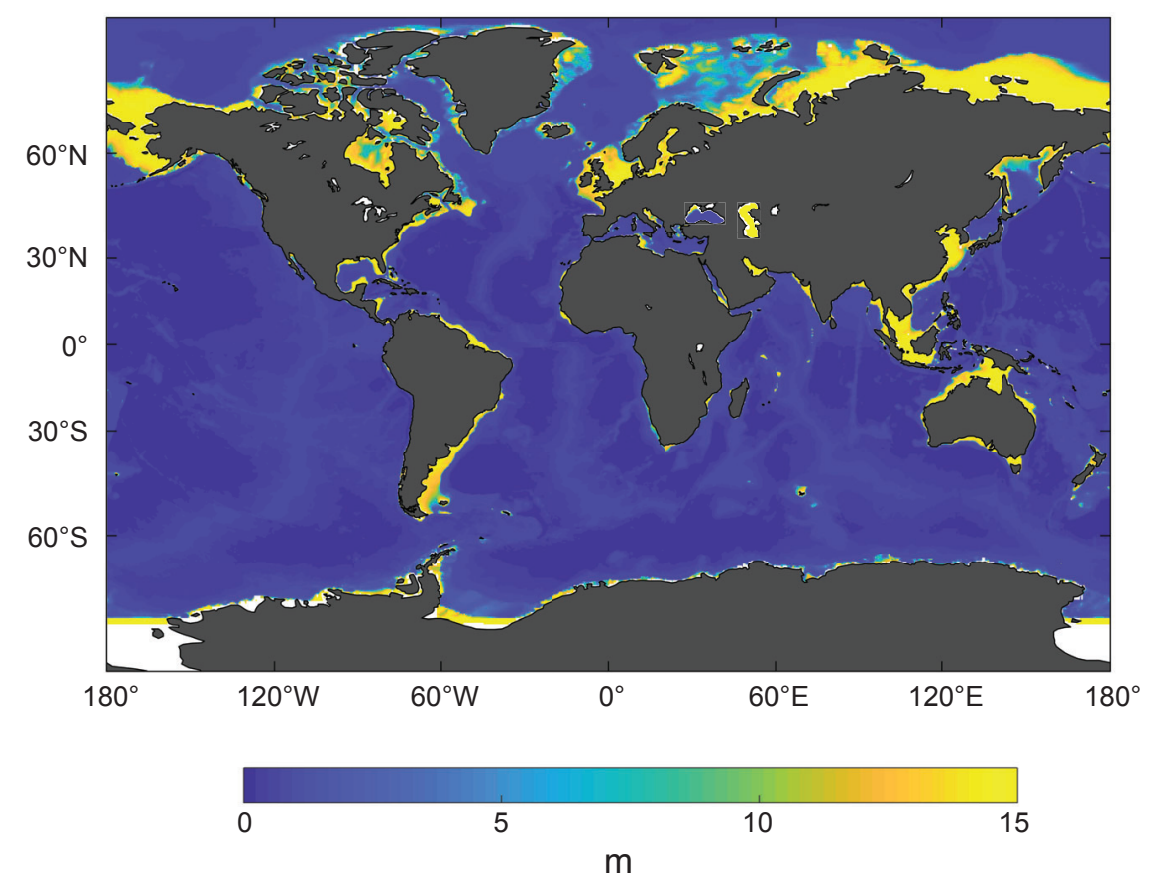

b)

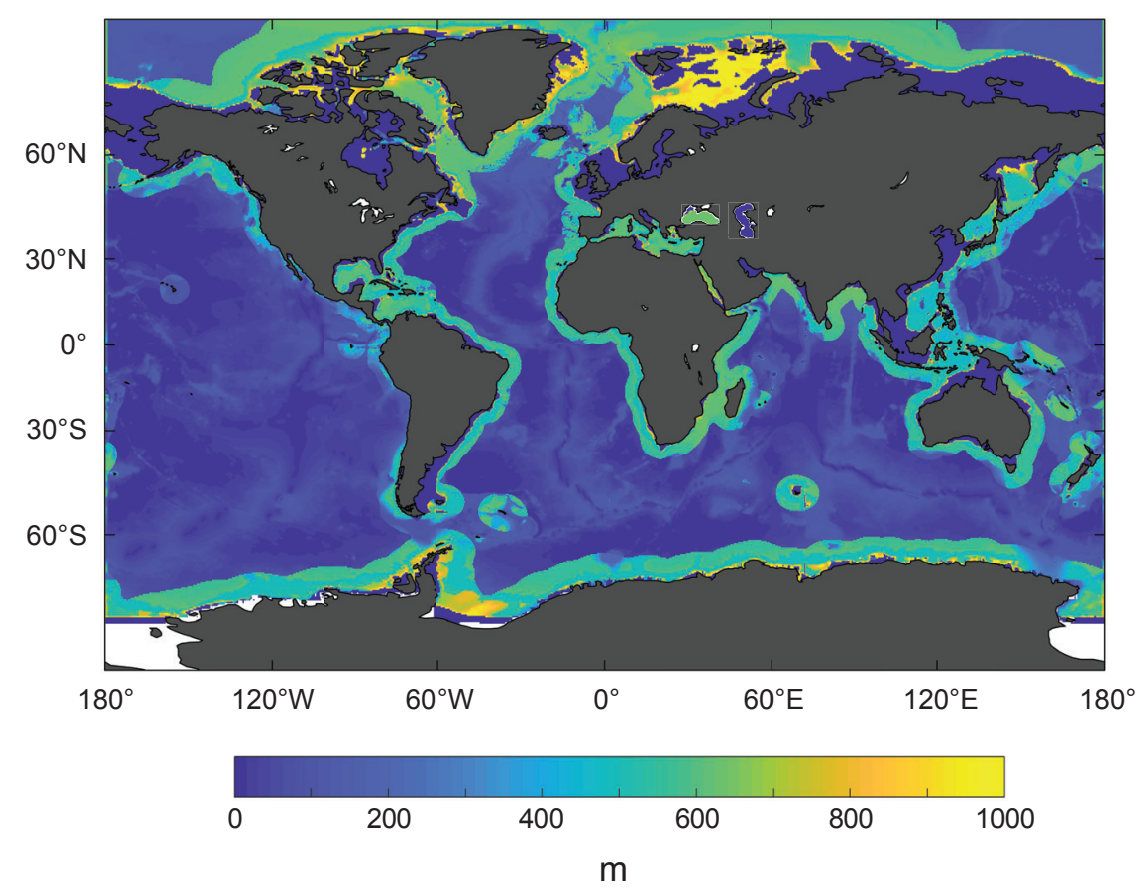

c)

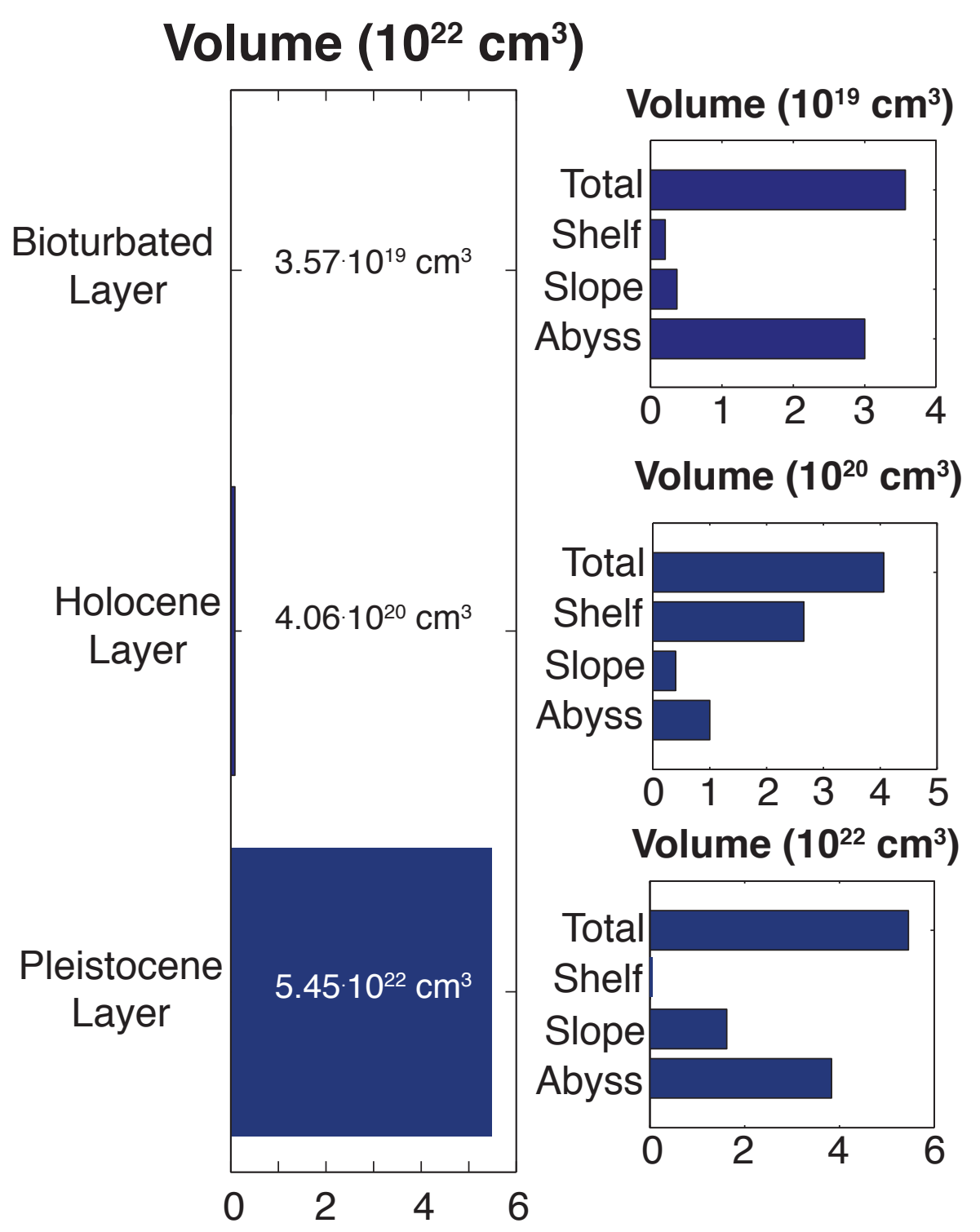


Figure 5

Baseline Scenario

(a)

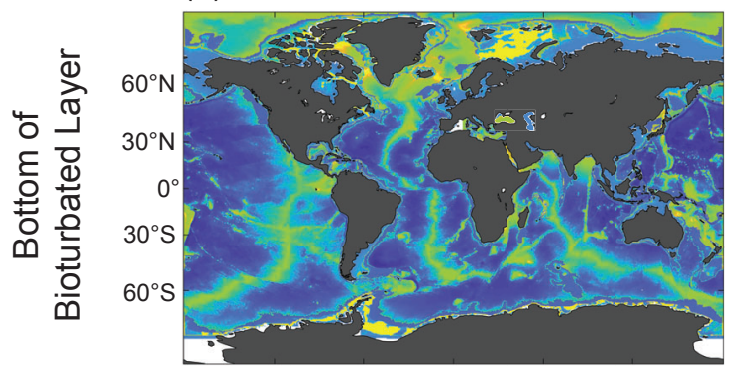

(b)

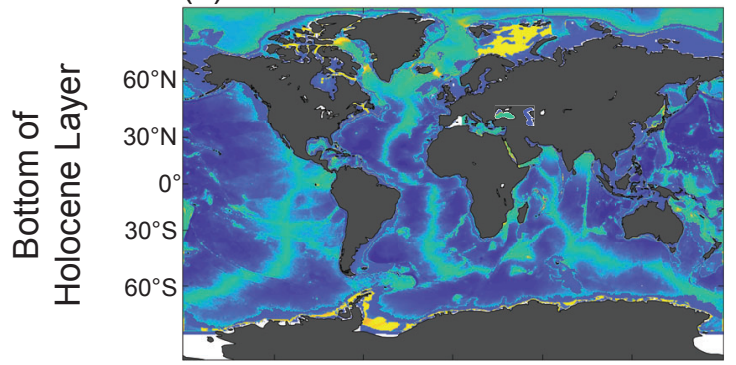

(c)

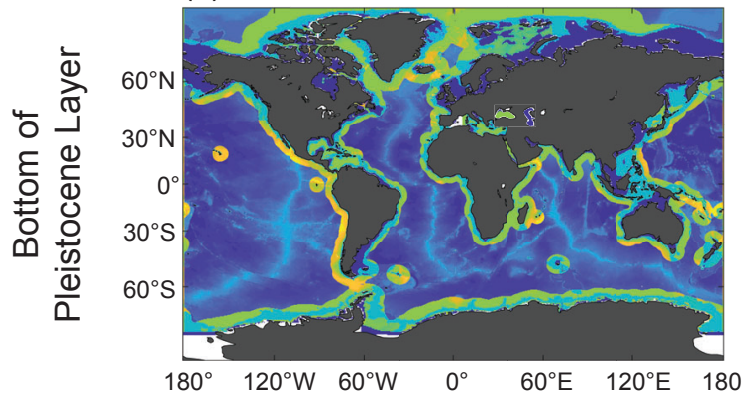

Low Reactivity Scenario

(d)

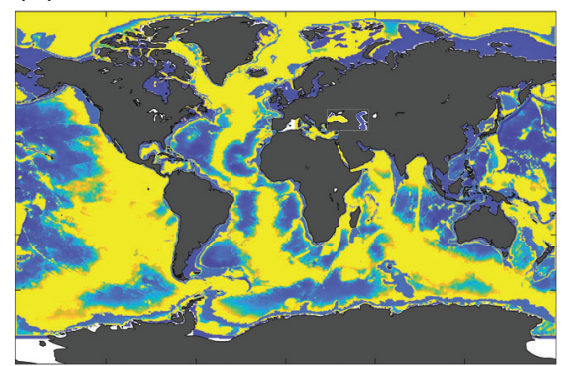

(e)

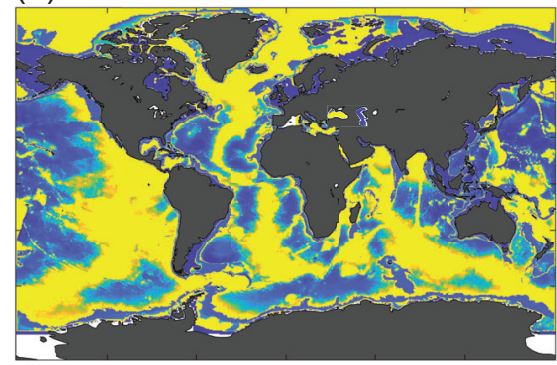

(f)

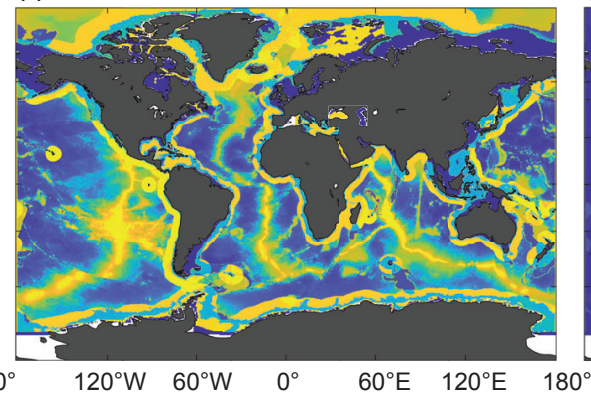

High Reactivity Scenario

(g)

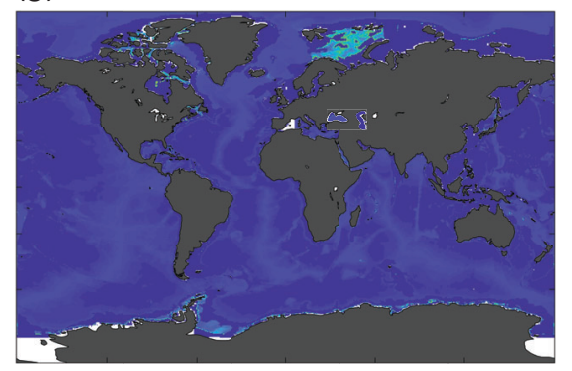

(h)

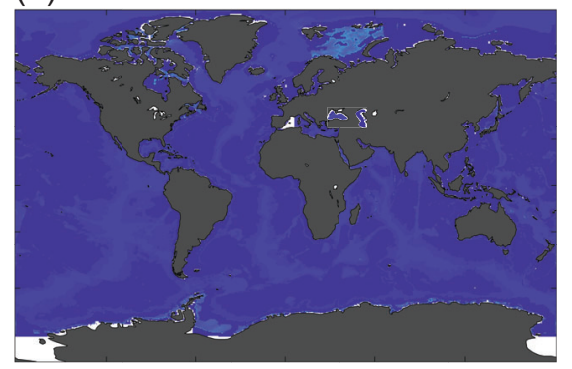

(i)

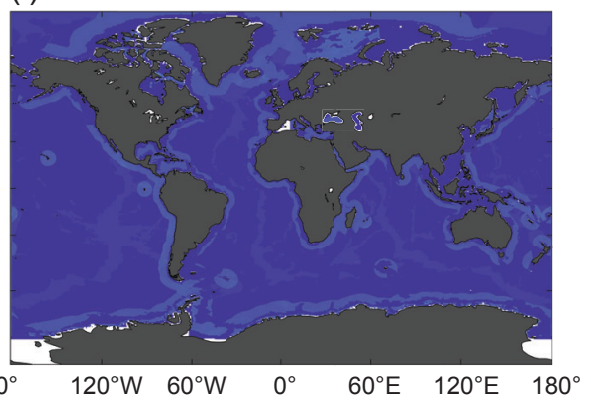

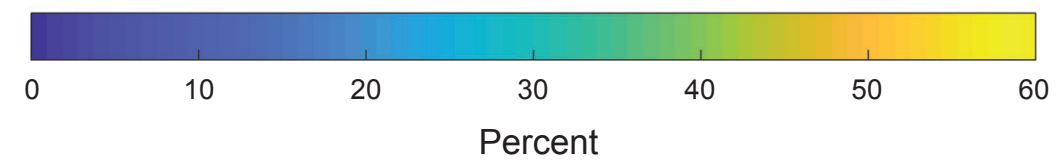


Figure 6

a) Holocene bioturbated

b) Non-bioturbated Holocene

c) Pleistocene
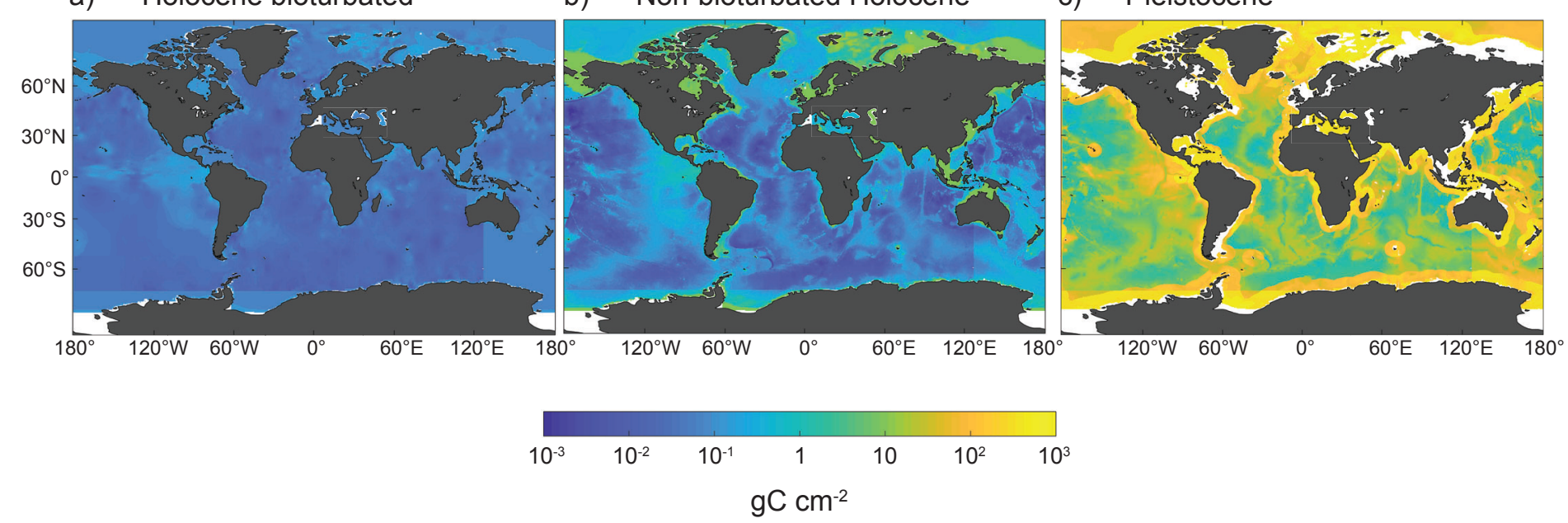
Figure 7

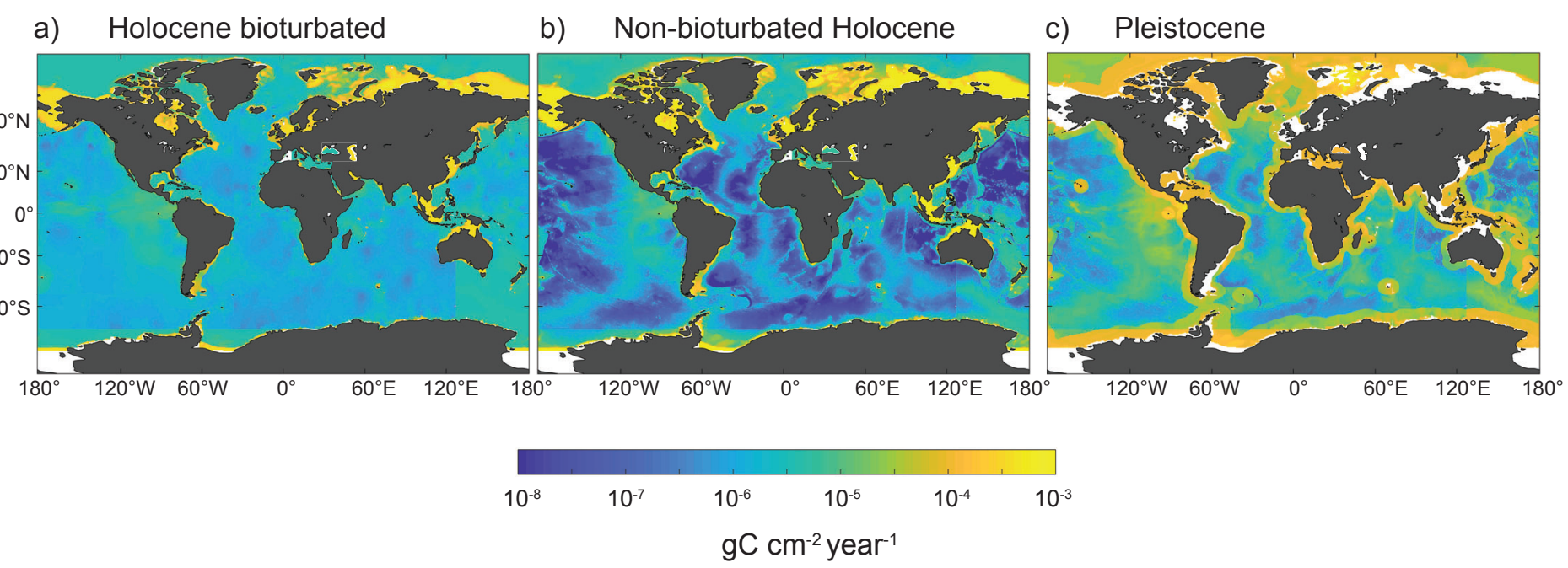


Figure 8

a)

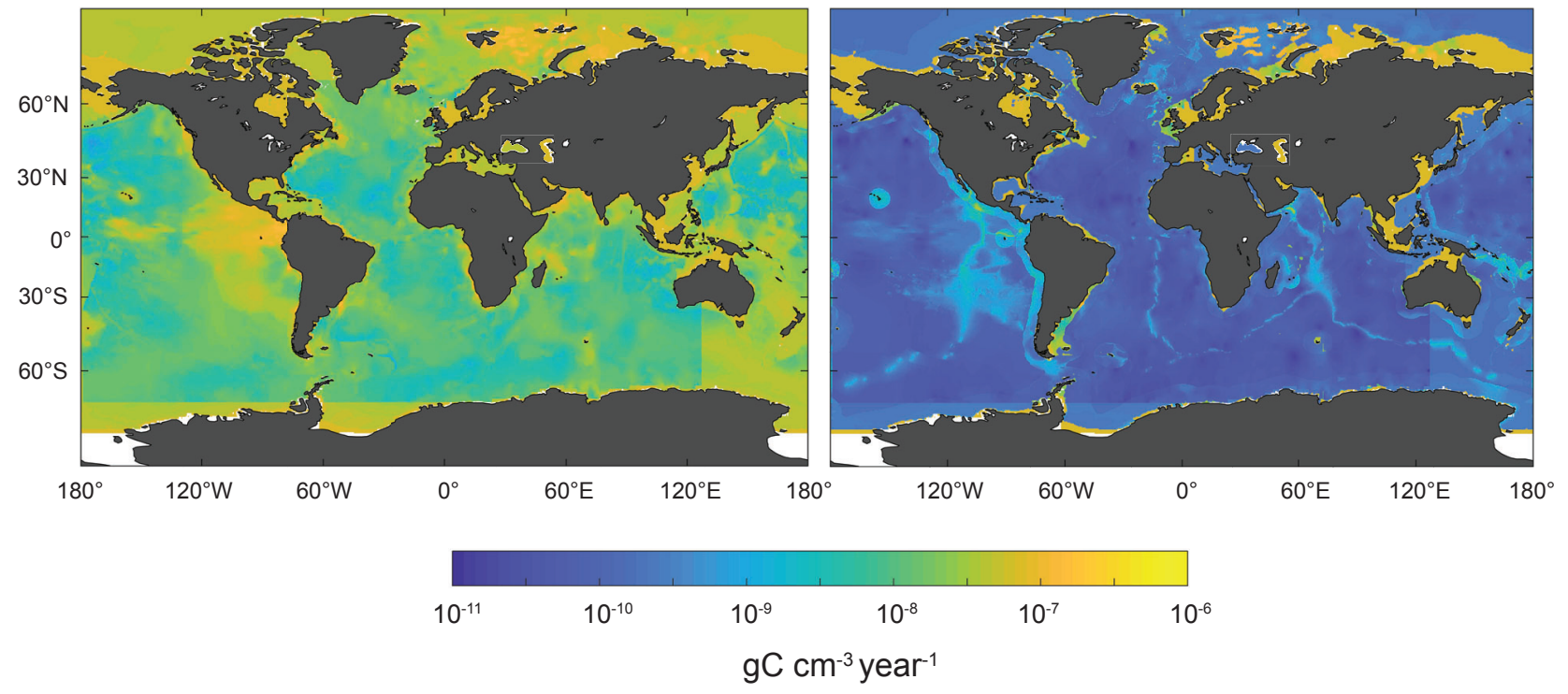


Figure 9
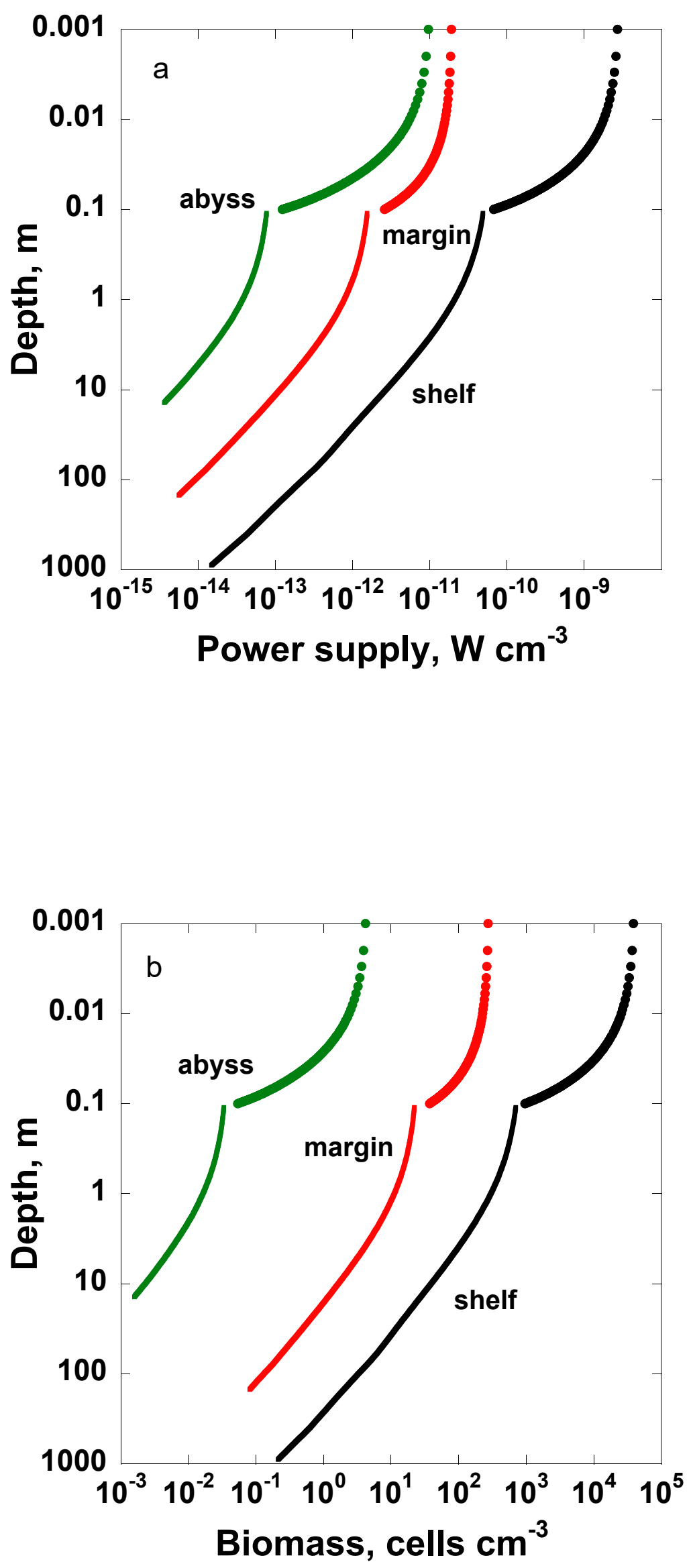